\title{
Feeding and energetics of the great scallop, Pecten maximus, through a DEB model
}

\author{
Romain Lavaud ${ }^{\mathrm{a}, *}$, Jonathan Flye-Sainte-Marie ${ }^{\mathrm{a}}$, Fred Jean ${ }^{\mathrm{a}}$, Antoine Emmery ${ }^{\mathrm{b}}$, \\ Øivind Strand ${ }^{\mathrm{c}}$, Sebastiaan A.L.M. Kooijman ${ }^{\mathrm{d}}$

\footnotetext{
a Laboratoire des sciences de l'environnement marin (UMR6539 CNRS/IRD/UBO), Institut Universitaire Européen de la Mer, Université de Brest, Plouzané, France

b Station expérimentale d'Argenton (Ifremer), Argenton, France

c Institute of Marine Research (IMR), Bergen, Norway
} \\ d Department of Theoretical Biology, Institute of Ecological Science, Vrije Universiteit, Amsterdam, The Netherlands
}

\section{A R T I C L E I N F O}

\section{Article history:}

Received 30 May 2013

Received in revised form 5 September 2013

Accepted 25 October 2013

Available online 5 November 2013

\section{Keywords:}

Pecten maximus

DEB theory

Synthesizing Units

Phytoplankton

Feeding process

Bay of Brest

\begin{abstract}
A B S T R A C T
We developed a full life-cycle bioenergetic model for the great scallop Pecten maximus relying on the concepts of the Dynamic Energy Budget (DEB) theory. The covariation method was implemented to estimate the parameters of a standard DEB model. Such models are able to predict various metabolic processes from a food availability marker and temperature in the environment. However, suspension-feeders are likely to feed on various trophic sources, from microalgae cells to detritus. They are also able to sort and select food particles very efficiently, depending on their size, energetic value or quality. The present model includes a mechanistic description of the feeding processes, based on Kooijman's Synthesizing Unit principle which allows to deal with several food sources. Moreover we tested the hypothesis of a differential selectivity between two potential substrates (phytoplankton cell and the remaining particulate organic matter). Simulations of shell length, daily shell growth rate, dry weight and gonado-somatic index (GSI) variations were realized and compared to field data from a monitoring conducted in the Bay of Brest (Brittany, France) for six years. The model shows its capacity to efficiently reproduce all life history traits of the wild great scallops. Predicted length data were estimated to the nearest millimeter. The fit of simulated weights to observed data was very satisfactory. GSI predictions were also in accordance with observations but improvements are required to better capture the sharp increase of gametogenesis at the beginning of the year. Finally, results bring evidences that $P$. maximus is actually preferentially feed on living algae cells rather than on the rest of organic particles.
\end{abstract}

(C) 2013 Elsevier B.V. All rights reserved.

\section{Introduction}

The great scallop Pecten maximus (Linnaeus, 1758) is a bivalve mollusk living in coastal environments of North-Western Atlantic, commercially important for fisheries and sea ranching. A large number of studies have long explored the physiological and ecological traits of this animal, both in controlled environment and in the wild (e.g. Antoine et al., 1979; Chauvaud et al., 2001, 2012; Laing, 2000, 2002; Mason, 1957; Paulet et al., 1997; Saout et al., 1999; Strohmeier et al., 2009). Its broad latitudinal and bathymetric distribution results in a variability of life history traits with a large ultimate size in Northern environments and small size in Southern areas and deep locations (Chauvaud et al., 2012). Known to feed mainly on phytoplankton and microphytobenthos (Chauvaud et al., 2001; Robert et al., 1994), its diet has also been reported to include bacteria and nanoplankton as well (Heral, 1989; Langdon and Newell, 1990; MacDonald et al., 2006; Nerot et al., 2012), but in proportion that still needs to be assessed. These two aspects of $P$. maximus

\footnotetext{
* Corresponding author. Tel.: +332984986 70; fax: + 33298498645 .

E-mail addresses: romain.lavaud@univ-brest.fr, romain.lavaud@hotmail.fr (R. Lavaud).
}

biology (growth and feeding) are key processes for a better comprehension of the physiology of this species.

Within the French project COMANCHE, we are trying to combine various scientific and economic approaches around the biology and exploitation of $P$. maximus in the English Channel region. The development of a bioenergetic individual-based model is a crucial step to combine hydrodynamic, larval development and dispersion models with population dynamic modeling. Thus we were motivated to set up a mechanistic model capable, with as few variables as possible, to simulate the evolution through time of diverse physiological traits that would serve as basis for fishery management.

We tried to combine knowledge accumulated about this species in a model for metabolic processes, which can give reliable insights on the physiological evolution of the organism and thus capture the variability observed in biological pattern. Dynamic Energy Budget theory (DEB, Kooijman, 2010) provides such a generalized, individual-based, bioenergetic framework suitable for linking levels of metabolic organization through a mechanistic model. It has been successfully applied to 240 species from fungi to mammals (Kooijman, 2013) and especially to bivalves species closely related to P. maximus such as Crassostrea gigas 
in the same taxonomic order (Alunno-Bruscia et al., 2011; Bernard et al., 2011; Bourlès et al., 2009; Cardoso et al., 2006; Pouvreau et al., 2006), Mytilus edulis (Cardoso et al., 2006; Rosland et al., 2009; Troost et al., 2010; Saraiva et al., 2011a), Ruditapes philippinarum (Flye-SainteMarie et al., 2007), Perna canaliculus (Ren and Ross, 2005), Cerastoderma edule (Cardoso et al., 2006; Troost et al., 2010; Wijsman and Smaal, 2013), Macoma balthica, Mya arenaria (Freitas et al., 2009) and Pinctada margaritifera (on the larval stage Thomas et al., 2011).

In this study we aim at developing the first DEB model for a member of the pectinid family, P. maximus. Using literature data we estimated the standard DEB parameters and built our model with the Synthesizing Unit concept (Kooijman, 2010). The inter-annual variability of several physiological processes of adult scallops was studied and compared to monitoring data gathered over six years in the Bay of Brest (Brittany, France). An innovative aspect of this work is the implementation of the hypothesis of a differential selectivity in food sources, tested using the Synthesizing Unit principle from Kooijman (2010).

\section{Material and methods}

\subsection{Model formulation}

The model developed in this study is based on the Dynamic Energy Budget theory (Kooijman, 2010). According to DEB theory the energetics of an organism can be described by the dynamics of three state variables: (1) the structural volume $V$ (somatic tissue excluding reserves), (2) the reserves $E$ and (3) the energy allocated to maturity and reproduction $E_{R}$. Trophic resource provides energy that fuels the reserve compartment. A fixed fraction $(\kappa)$ of energy flux from reserve is then allocated to somatic growth plus its maintenance, with a priority given to maintenance. The remaining fraction $(1-\kappa)$ is used for maturity maintenance, maturation (in embryos and juveniles) and reproduction (i.e. gamete production in adults). A conceptual scheme, illustrating the modeled energy flows through the scallop, is given in Fig. 1. Notation of the variables and parameters is from Kooijman (2010) (Table 1).

In this study, we paid a particular attention to the feeding process, which is rather complex in suspension feeders (Cranford et al., 2011; Ward and Shumway, 2004). Briefly, the filtering process in bivalves

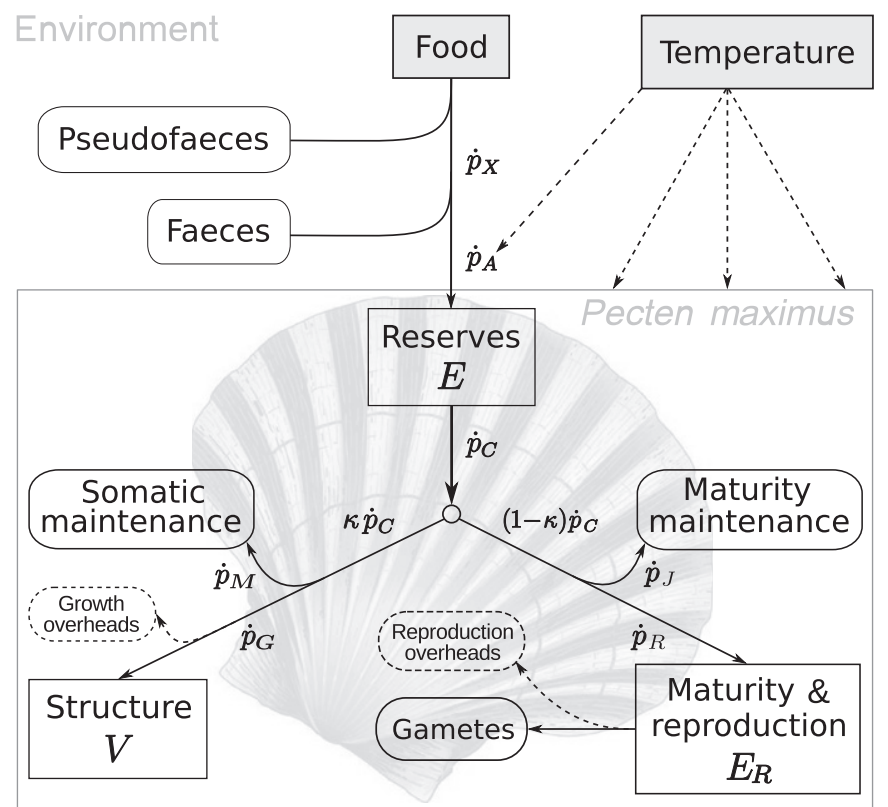

Fig. 1. Conceptual scheme of the DEB model applied to the scallop P. maximus. Forcing variables (food and temperature) are in gray; state variables are Reserves $(E)$, Structure $(V)$ and Maturity \& reproduction $\left(E_{R}\right)$, in white boxes. Dark arrows are energy fluxes and dotted ones show temperature influence on these rates.
Table 1

Equations for the calculations of the variables of the P. maximus energy budget model.

\begin{tabular}{|c|c|c|c|}
\hline Name of the variable & Symbol & Unit & Equation \\
\hline Feeding rate of $X$-type particles & $h_{X A m}$ & $\# \cdot \mathrm{d}^{-1} \cdot \mathrm{cm}^{-2}$ & $=\frac{J_{x a m}}{M x}$ \\
\hline Feeding rate of $Y$-type particles & $h_{X A m}$ & $\# \cdot \mathrm{d}^{-1} \cdot \mathrm{cm}^{-2}$ & $=\frac{\substack{M_{Y \rightarrow} \\
M_{Y}}}{M_{Y}}$ \\
\hline Reserve density & {$[E]$} & $\mathrm{J} \cdot \mathrm{cm}^{-3}$ & $=\stackrel{\substack{E \\
V}}{M_{Y}}$ \\
\hline Assimilation rate & $\dot{p}_{A}$ & $\mathrm{~J} \cdot \mathrm{d}^{-1}$ & $=J_{E A} \mu_{E} V^{2 / 3}$ \\
\hline Mobilization rate & $\dot{p}_{C}$ & $J \cdot d^{-1}$ & $=\frac{[E]}{\left[E_{G}\right]+K[E]}\left(\frac{E_{G} \dot{v}}{V^{1 / 3}}+\left[\dot{P}_{M}\right]\right)$ \\
\hline Somatic maintenance & $\dot{p}_{M}$ & $\mathrm{~J} \cdot \mathrm{d}^{-1}$ & $=\left[\dot{p}_{M}\right] V$ \\
\hline Maturity maintenance coefficient & $\dot{p}_{J}$ & $\mathrm{~J} \cdot \mathrm{d}^{-1}$ & $=E_{H} k_{J}$ \\
\hline Structural growth & $\dot{p}_{G}$ & $\mathrm{~J} \cdot \mathrm{d}^{-1}$ & $=\max \left(0, \kappa \dot{p}_{C}-\dot{p}_{M}\right)$ \\
\hline Allocation to reproduction buffer & $\dot{p}_{R}$ & $J \cdot d^{-1}$ & $=\max \left(0,(1-\kappa) \dot{p}_{C}-\dot{p}_{J}\right)$ \\
\hline $\begin{array}{l}\text { Shrink to pay somatic } \\
\text { maintenance }\end{array}$ & $\dot{p}_{S 1}$ & $\mathrm{~J} \cdot \mathrm{d}^{-1}$ & $=\max \left(0, \dot{p}_{M}-\kappa \dot{p}_{C}\right)$ \\
\hline $\begin{array}{l}\text { Shrink to pay maturity } \\
\text { maintenance }\end{array}$ & $\dot{p}_{52}$ & $J \cdot d^{-1}$ & $=\max \left(0, \dot{p}_{J}-(1-\kappa) \dot{p}\right)$ \\
\hline Resorption of gonad & $\dot{p}_{R S}$ & $\mathrm{~J} \cdot \mathrm{d}^{-1}$ & $=\frac{\dot{p}_{R} \kappa_{R}+E_{R} \frac{1}{4}}{\kappa_{R}}$ \\
\hline Lysis of structure & $\dot{p}_{V S}$ & $J \cdot d^{-1}$ & $=\frac{\left.\left(\dot{p}_{S 1}+\dot{p}_{S 2}\right)-\dot{p}_{R S} \kappa_{R}\right) d_{V d}}{\left.\kappa_{R} \mu_{E}\right)}$ \\
\hline
\end{tabular}

can be described as follows. A water current is generated through the pallial cavity by ciliary activity of the gills. Water is then sieved by the gills, the amount of water totally cleared of its particles per unit of time is denoted as clearance (or filtration) rate $\dot{F}_{X}$. For each food particle present in the surrounding water, with a density $X$, the flux of particles extracted from the environment, known as consumption rate, can be assessed by $X \dot{F}_{X}$. Rubbed into mucus strings, food particles are then transported to the aboral side of the gills where labial palps sort and bring food pellets to the mouth for ingestion; this ingestion rate is denoted as $\dot{J}_{X m}$. Suspension feeding bivalves are known to feed upon various trophic sources (see e.g. Bachok et al., 2009; Chauvaud et al., 2001; Kamermans, 1994; MacDonald et al., 2006; Nerot et al., 2012; Yokoyama et al., 2009) and they are subsequently able to develop a plastic trophic niche, variable in space and time as an adaptation/ acclimation to available trophic resources and depending on their development stage (Marín Leal et al., 2008; Rossi et al., 2004). Filtration, ingestion and assimilation processes are characterized by a capacity to select and sort potential food particles, via gill crossing retention, labial palp selectivity, inner digestive gland sorting and differential assimilation rates. Moreover, many studies focusing on modeling the energy dynamics of filter feeders have reported the need (Alunno-Bruscia et al., 2011; Bernard et al., 2011) and the benefit (Saraiva et al., 2011b; Troost et al., 2010) of adding a second food source to forcing variables to improve the food proxy. Thus, to model energy acquisition and afterwards its dynamics in P. maximus we focused on two concepts: (1) the processing of two types of food substrates and (2) the selectivity of food particles of different origins and energetic values.

In order to address these issues we chose to work with the concept of Synthesizing Units (SUs, Kooijman, 1998, 2006, 2010; Saraiva et al., 2011b), considered as generalized enzymes that transform an arrival flux of substrates into a production flux of products. Here food particles are considered as substrates and reserves as products. During the processing (handling time), no substrate particles are accepted by the SU, i.e. while handling, the binding probability for each arriving substrate will be null. SUs allow to deal with different types of food to test some patterns in feeding such as selectivity of substrates. We used two potential trophic source markers: algal cell counting and the rest of particulate organic matter (POM, i.e. non algal organic particles). Substrates were respectively called $S_{X}$ for cell counting and $S_{Y}$ for POM. The arrival flux of food particles was taken to be proportional to the density in spatially homogeneous environments Kooijman, 2010, which is the case in aquatic environments. We worked with interacting substitutable substrates that are bound in a sequential fashion (Fig. 2). This scheme illustrates the possibility for a free $\mathrm{SU}(\theta$.) to bind to either a substrate particle from type $S_{X}$ or $S_{Y}$ to form a SU- $S_{X}$ complex $\left(\theta_{X}\right)$ or a SU- $S_{Y}$ complex $\left(\theta_{X}\right)$ respectively. Moreover, a substrate $S_{X}$ can replace a $S_{Y}$ in a $\operatorname{SU}-S_{Y}$ complex $\left(\theta_{Y}\right)$ to form a SU- $S_{X}$ complex $\left(\theta_{X}\right)$, releasing an 


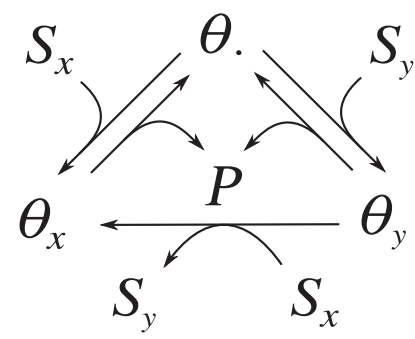

Fig. 2. Graphical representation of the preferential interaction between substrates in the Synthesizing Unit concept (Kooijman, 2010) that allows the substitution of one substrate type to another. $S_{X}$ is the substrate corresponding to the microalgal cells and $S_{Y}$ the one for remaining POM. $\theta$. Represents a free SU fraction while $\theta_{X}$ and $\theta_{Y}$ are SU fractions bound respectively to a X-type food particle and a Y-type food particle. $P$ stands for the product released after transformation of the substrate.

untransformed substrate $S_{Y}$. Each food type contributes to the production of reserves, specified in yield coefficients $\left(y_{E X}\right.$ and $\left.y_{E Y}\right)$ that were here treated as constant. Given the dissociation rate parameters $\dot{k}_{X}$ and $\dot{k}_{Y}$, the binding parameters $\dot{b}_{X}$ and $\dot{b}_{Y}$ and the interaction affinities $\dot{b}_{X Y}$ and $\dot{b}_{Y X}$, the changes in binding fractions for substrates $X$ and $Y$ are:

$\frac{d}{d t} \theta .=\dot{k}_{X} \theta_{X}+\dot{k}_{Y} \theta_{Y}-\left(\dot{b}_{X} X+\dot{b}_{Y} Y\right) \theta$

$\frac{d}{d t} \theta_{X}=-\dot{k}_{X} \theta_{X}+\dot{b}_{X} X \theta \cdot-\dot{b}_{Y X} Y \theta_{X}+\dot{b}_{X Y} X \theta_{Y}$

$\frac{d}{d t} \theta_{X}=-\dot{k}_{X} \theta_{X}+\dot{b}_{X} X \theta-\dot{b}_{X} Y \theta_{X}+\dot{b}_{X Y} X \theta_{Y}$

$\frac{d}{d t} \theta_{Y}=-\dot{k}_{Y} \theta_{Y}+\dot{b}_{Y} Y \theta .+\dot{b}_{X X} Y \theta_{X}-\dot{b}_{X Y} X \theta_{Y}$

where $1=\theta+\theta_{X}+\theta_{Y}$ and $\mathrm{X}$ and $\mathrm{Y}$ stand for the densities of substrates $S_{X}$ and $S_{Y}$ in a number of particle per liter, respectively. The pseudo steady state fractions are:

$\theta_{X}^{*}=\alpha_{Y} \frac{\dot{b}_{X} X-\beta_{X} \dot{b}_{Y} Y}{\alpha_{X} \alpha_{Y}-\beta_{X} \beta_{Y}} ; \quad \theta_{Y}^{*}=\alpha_{X} \frac{\dot{b}_{Y} Y-\beta_{Y} \dot{b}_{X} X}{\alpha_{X} \alpha_{Y}-\beta_{X} \beta_{Y}}$

with

$\alpha_{X}=\dot{k}_{X}+\dot{b}_{X} X+\dot{b}_{Y X} Y ; \quad \alpha_{Y}=\dot{k}_{Y}+\dot{b}_{Y} Y+\dot{b}_{X Y} X ;$

$\beta_{X}=\dot{b}_{X} X-\dot{b}_{X Y} X ; \quad \beta_{Y}=\dot{b}_{Y} Y-\dot{b}_{Y X} Y$.

The preference hypothesis is transcribed into the model by changing $\dot{b}_{X Y}$ and $\dot{b}_{Y X}$, in such a way that the SU would be able to change from substrate $X$ to substrate $Y$, i.e. setting one probability superior to the other. $\dot{b}_{X Y}$ and $\dot{b}_{Y X}$ were first turned into $\left\{\dot{b}_{X Y}\right\}=\frac{\dot{b}_{X Y}}{L^{2}}$ and $\left\{\dot{b}_{Y X}\right\}=\frac{\dot{b}_{Y X}}{L^{2}}$, to get rid of size dependency. $\left\{\dot{b}_{X Y}\right\}$ was set at 0 and $\left\{\dot{b}_{X Y}\right\}$ was taken equal to the maximum specific filtration rate for $X$-type substrate, $\left\{\dot{F}_{X m}\right\}$. In this case a change in the substrate to process may occur in one direction only. When both substrates are available, this rule leads to an automatic substitution of the counter-selected substrate (POM particle), already bound to a SU, by the preferred food type (here algae cells). Dissociation rates relate to the maximum specific feeding rates as $\dot{k}_{X}=\left\{\dot{h}_{X A m}\right\} L^{2}$ and $\dot{k}_{Y}=\left\{\dot{h}_{Y A m}\right\} L^{2}$, where $L$ is the structural length of the individual and $\left\{\dot{h}_{X A m}\right\}$ and $\left\{\dot{h}_{Y A m}\right\}$ are the maximum specific feeding rates $\left(\# \cdot \mathrm{d}^{-1} \cdot \mathrm{cm}^{-2}\right)$, given by:

$\left\{\dot{h}_{X A m}\right\}=\frac{\left\{\dot{J}_{X A m}\right\}}{M_{X}} \quad$ with $\quad\left\{\dot{J}_{X A m}\right\}=\frac{\left\{\dot{p}_{A m}\right\}}{\left(\mu_{E} y_{E X}\right)}$
$\left\{\dot{h}_{Y A m}\right\}=\frac{\left\{\dot{J}_{Y A m}\right\}}{M_{Y}} \quad$ with $\quad\left\{\dot{J}_{Y A m}\right\}=\frac{\left\{\dot{p}_{A m}\right\}}{\left(\mu_{E} y_{E Y}\right)}$

where $\left\{\dot{J}_{X A m}\right\}$ and $\left\{\dot{J}_{Y A m}\right\}$ are the maximum specific ingestion rates (mol $\left.\cdot \mathrm{d}^{-1} \cdot \mathrm{cm}^{-2}\right),\left\{\dot{p}_{A m}\right\}$ is the maximum specific assimilation rate $\left(\mathrm{J} \cdot \mathrm{d}^{-1} \cdot \mathrm{cm}^{-2}\right), \mu_{E}$ is the chemical potential of reserve $\left(\mathrm{J} \cdot \mathrm{mol}^{-1}\right)$ and $y_{E X}$ and $y_{E Y}$ are the yields of reserve on compounds $\mathrm{X}$ and $\mathrm{Y}$ respectively $\left(\mathrm{mol} \cdot \mathrm{mol}^{-1}\right)$. Values for these parameters are given in Table 3.

Finally, the association rates relate to the maximum specific searching rates as $\dot{b}_{X}=\left\{\dot{F}_{X m}\right\} L^{2}$ and $\dot{b}_{Y}=\left\{\dot{F}_{Y m}\right\} L^{2}$. Thus the specific assimilation rate for reserve can be written as:

$\dot{J}_{E A}=y_{E X}\left\{\dot{J}_{X A m}\right\} f_{X}+y_{E Y}\left\{\dot{J}_{Y A m}\right\} f_{Y}$

with

$f_{X}=\alpha_{Y}\left\{\frac{\left.\dot{F}_{X m}\right\} X-\beta_{X} \dot{b}_{Y} Y}{\alpha_{X} \alpha_{Y}-\beta_{X} \beta_{Y}} ; \quad f_{Y}=\alpha_{X}\left\{\frac{\left.\dot{F}_{Y m}\right\} Y-\beta_{Y} \dot{b}_{X} X}{\alpha_{X} \alpha_{Y}-\beta_{X} \beta_{Y}}\right.\right.$

$\alpha_{X}=\left\{\dot{h}_{X A m}\right\}+\left\{\dot{F}_{X m}\right\} X+\left\{\dot{b}_{Y X}\right\} Y ; \quad \alpha_{Y}=\left\{\dot{h}_{Y A m}\right\}+\left\{\dot{F}_{Y m}\right\} Y+\left\{\dot{b}_{X Y}\right\} X$

$\beta_{X}=\left\{\dot{F}_{X m}\right\} X-\left\{\dot{b}_{X Y}\right\} X ; \quad \beta_{Y}=\left\{\dot{F}_{Y m}\right\} Y-\left\{\dot{b}_{Y X}\right\} Y$

In order to test the hypothesis of a selectivity in feeding in P. maximus, a classical functional response was also calculated, using only one food source (phytoplankton cells). This response to food density variations is based on the Holling type II functional response (Kooijman, 2010): $f=\frac{X}{X+X_{k}}$, with $X$ the algae cell concentration $\left(\# \cdot \mathrm{L}^{-1}\right.$ ) and $X_{K}$ the half-saturation coefficient $\left(\# \cdot \mathrm{L}^{-1}\right)$. The value of this parameter was calibrated for each year.

Once assimilation has been implemented, reserve dynamics can be treated. Energy conservation law implies that reserve dynamics amounts to the difference between the assimilation rate $\dot{p}_{A}$ and the utilization rate of reserves $\dot{p}$. The structural growth is provided with a fraction $\kappa$ of this mobilized energy from which somatic maintenance requirements are first paid. The rest of energy flux from the reserve compound is allocated in priority to maturity maintenance and then to the reproduction buffer $E_{R}$. During periods of low food availability or prolonged starvation (especially in winter), P. maximus is known to undergo a sharp decrease in flesh weight (Comely, 1974; Pazos et al., 1997). In fact, the flux of energy coming from reserves is not sufficient to "pay" maintenance costs (both $\dot{p}_{M}$ and $\dot{p}_{J}$ ). The energy that has to be mobilized to pay somatic maintenance $\left(\dot{p}_{S 1}\right)$ and maturity maintenance $\left(\dot{p}_{S 2}\right)$ is taken from the reproduction buffer (resorption of gonad, $\dot{p}_{R S}$ ) and if the reproduction buffer is empty, maintenance costs are "paid" from the structural volume (lysis of structure, $\dot{p}_{V S}$ ).

The dependency of physiological rates on body temperature in ectotherms (in which body temperature equals external temperature) has been described by the Arrhenius relationship within a species-specific tolerance range of temperature (Kooijman, 2010). The following relationship was used to correct all model fluxes for temperature:

$\dot{k}(T)=\dot{k}_{1} T_{C} \quad$ with $\quad T_{C}=\frac{\exp \left(\frac{T_{A}}{T_{1}}-\frac{T_{A}}{T}\right)\left(1+\exp \left\{\frac{T_{A L}}{T_{1}}-\frac{T_{A A}}{T_{L}}\right\}\right)}{1+\exp \left(\frac{T_{A L}}{T}-\frac{T_{A L}}{T_{L}}\right)}$

where $\dot{k}(T)$ is the value of the physiological rate at temperature $T, \dot{k}_{1}$ is the physiological rate at the reference temperature $T_{1}, T_{A}$ is the Arrhenius temperature, $T_{L}$ is the lower boundary of the tolerance range, and $T_{A L}$ is the Arrhenius temperature for the rate of decrease at the lower boundary. All temperatures are expressed in Kelvin (K). 


\subsection{Parameter estimation}

The Arrhenius temperature was estimated by fitting the previous equation in a composite data set relating physiological rates (respiration, growth, filtration, assimilation) to temperature, constructed from data available in literature (Laing, 2000, 2002, 2004) and from unpublished studies in the Bay of Brest (Chauvaud and Paulet, unpublished data). A reference temperature $\left(T_{1}\right)$ of $288 \mathrm{~K}$ was chosen. We applied the covariation method for parameter estimation according to the procedure described by Lika et al. (2011) that allows to estimate all parameters of the standard DEB model from empirical datasets of the literature (Table 4). Part of these observed data consists of single values, named zero-variate data, such as age, weight and size at the larval stage (Buestel et al., 1982; Gruffydd and Beaumont, 1972; Samain et al., 1986; Shumway and Parsons, 2006, at puberty (Shumway and Parsons, 2006) and at the adult period (Le Pennec et al., 2003; Paulet and Fifas, 1989; Paulet et al., 1997; Shumway and Parsons, 2006). The other type of observations used for parameter calibration is a data set of 288 shell length over age values (EVECOS database provided by "Observatoire Marin de l'IUEM, INSU,Plouzané"). The covariation method is a singlestep procedure based on the simultaneous minimization of the weighted sum of squared deviations between all observation data sets and model predictions. Weight coefficients can be applied to zero-variate data, in order to quantify the certainty of life history traits gathered from literature (on the basis of their reliability and occurrence). Therefore, little less weight was given to puberty data as the timing of this maturity threshold is rather imprecise. Likewise, as ultimate length is an empirical measurement, hardly reproducible, a lower weight coefficient was also applied to this value. The relevance of the parameter set was assessed by a mean relative error calculation (mre).

\subsection{Study site, forcing and calibration data}

To test the estimated parameters we used a data set of a monthly monitoring of $P$. maximus bank located in the Roscanvel site, in the central area of the Bay of Brest (Fig. 3). This location is a coastal semienclosed area located in Western France. It is under the influence of high tides and freshwater inputs from two rivers and is connected to the open ocean by a narrow strait ( $2 \mathrm{~km}$ wide). Biometry measurements of scallops from the Roscanvel bank $\left(4^{\circ} 30^{\prime} \mathrm{W}, 48^{\circ} 20^{\prime} \mathrm{N}\right)$ have been monitored during several decades (1977 to 2004) and provide a large data set, also including environmental variables. Twenty scallops from the three-year age cohort (2.5 to 3.5 years old) have been collected twice a month (EVECOS database provided by "Observatoire Marin de l'IUEM, INSU, Plouzané").

Dry weight of each organ, shell height and gonado-somatic index (gonad dry weight over total body dry weight) were measured on these individuals. In order to compare weight values obtained for different sized animals, dry weights were corrected for size differences between individuals following the formula of Bayne et al. (1987):

$W_{r}=\left(\frac{L_{r}}{L_{m}}\right)^{3} W_{m}$

where $W_{r}$ is the recalculated weight of an individual of standard shell height $L_{r}$ and $W_{m}$ is the measured weight for an individual of measured shell height $L_{m}$. Length were estimated after measuring the mean daily shell growth rate (DSGR) over an entire growth season using the method proposed by Chauvaud et al. (2012). Each year, five individuals were sampled in December, i.e. after the growth cessation, to capture the entire growth season. Five other individuals harvested in August were used to assign calendar dates to each increment, by knowing the sampling date of the last formed increment. A synchronization procedure was used between the individual growth trajectories within each pool by minimizing the sum of the differences between individual series considered two-by-two. Growth trajectories from the summer pool and the winter pool were finally adjusted in the same way to assign calendar dates to the full year data set.

Fig. 4 shows the environmental parameters used as forcing variables in the model. Daily temperature has been measured at the watersediment interface in the Roscanvel bank from 1998 until 2000. A linear regression between registered temperature at Roscanvel and those from the SOMLIT probe in Sainte-Anne (data provided by "Service d'Observation en Milieu Littoral, INSU-CNRS, Brest"), allowed the reconstruction of bottom temperature in Roscanvel between 2001 and 2003. Two food proxies have been monitored: the particulate organic matter (POM, in $\mathrm{mg} \cdot \mathrm{l}^{-1}$ ) and the phytoplankton concentration (in cell $\cdot \mathrm{l}^{-1}$ ). These data come from an instrumented site which is monitored by the REPHY network (PHYtoplankton and PHYcotoxins monitoring NEtwork, Ifremer). POM data in $\mathrm{mg} \cdot \mathrm{l}^{-1}$ were transformed into a number of particles per liter by considering an average particle diameter of $30 \mu \mathrm{m}$ (weight of $1.4 \cdot 10^{-5} \mathrm{~g}$ for a density of 1 ) per POM particle. Environmental measurements were linearly interpolated to fit the time step of the simulations.

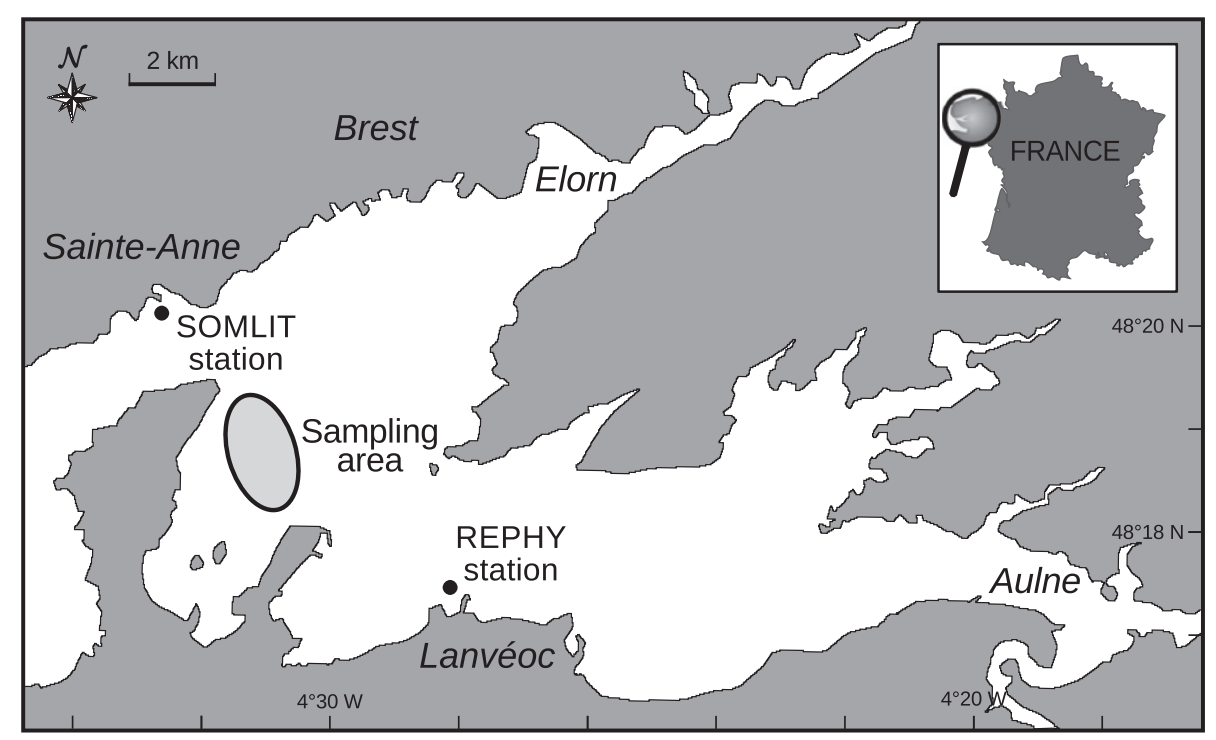

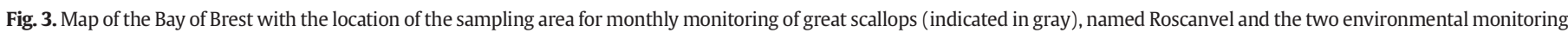
sites: the REPHY station at Lanvéoc and the SOMLIT stationat Sainte-Anne. 


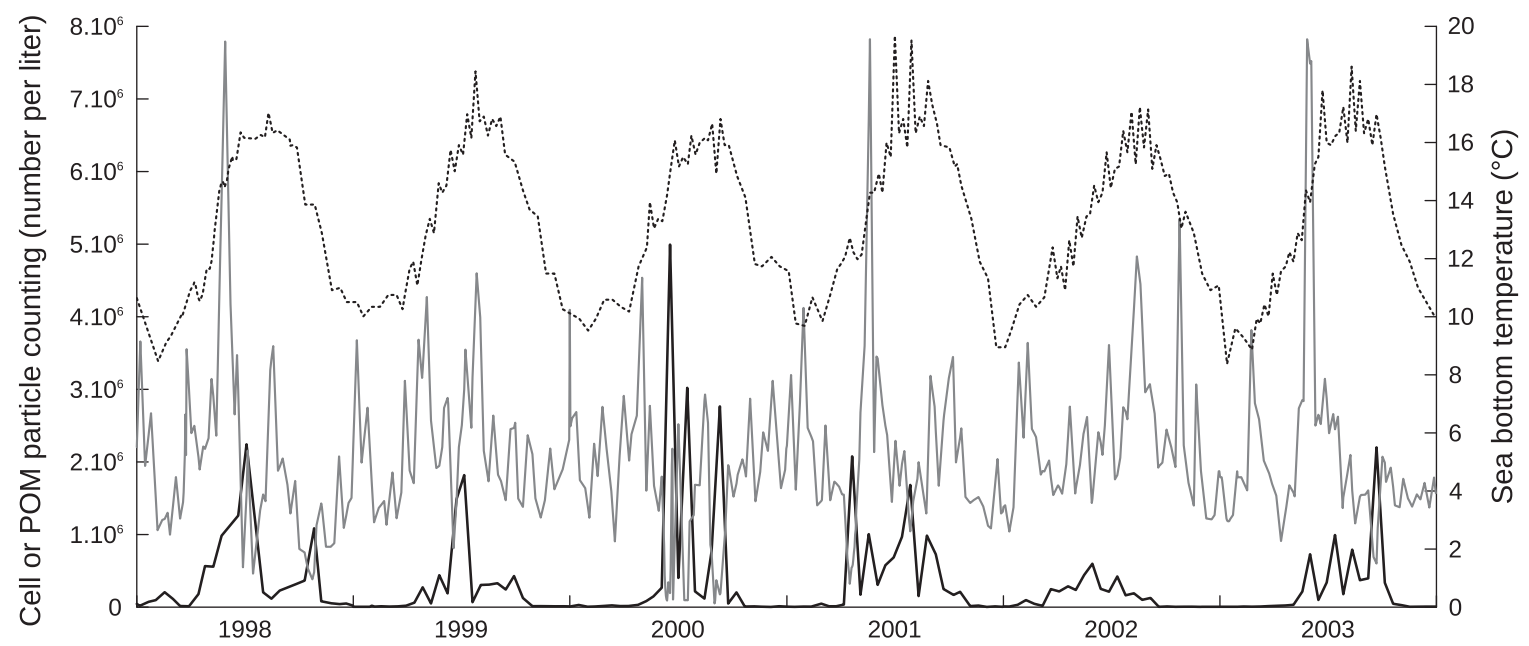

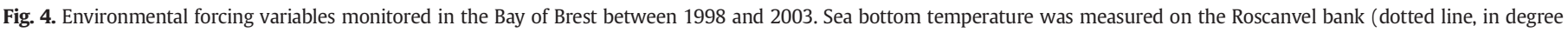

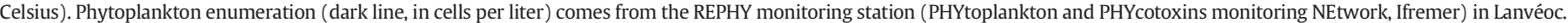

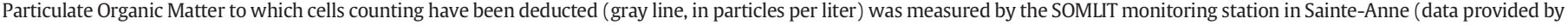
"Service d'Observation en Milieu Littoral, INSU-CNRS, Brest").

\subsection{Model simulations}

Simulations were performed using GNU Octave software (Eaton et al., 2008). Initial values for the state variables are obtained from observed measurements in the first sampling of the year (Table 2). A Eulerian integration method was used to study the dynamics of each state variable in time. As the individuals are three-year-old and fully mature (Antoine et al., 1979), the initial amount of maturity is taken to be equal to the maturity at puberty (supposed to be maintained during the adult stage, Kooijman, 2010). Using the DEB model developed for $P$. maximus we simulated the body dry weight, the shell height, the DSGR and the gonado-somatic index between 1998 and 2003. The evolution of shell height over time has been simulated from the relationship: $V=\left(\delta_{\mathscr{1}} L_{O b s}\right)^{3}$, where $L_{O b s}$ is in $\mathrm{cm}$. The gonado-somatic index (GSI) was calculated as a ratio between the wet weight of reserves allocated to reproduction $\left(W_{E_{R}}\right)$ and the cubic shell length. Total body dry weight and GSI were calculated according to the following formulas:

$W=V d_{V d}+\left[\left(E+E_{R}\right) \frac{w_{E}}{\mu_{E}}\right]$

$G S I=\frac{W_{E_{R}}}{L s^{3}} 1000$ with $\quad W_{E_{R}}=\frac{E_{R} \frac{w_{E}}{\mu_{E}}}{d_{V d}}$

where $w_{E}$ is the molar weight of reserve $\left(\mathrm{g} \cdot \mathrm{mol}^{-1}\right), \mu_{E}$ is the energy content of $1 \mathrm{~g}$ of reserve $\left(\mathrm{J} \cdot \mathrm{mol}^{-1}\right)$ and $d_{V d}$ is the wet weight to dry weight ratio.

In the DEB theory, strategies for handling the reproduction buffer and spawning are species-specific. In P. maximus, gamete releasing is asynchronous, partial and has been reported to be influenced by four parameters: temperature, food density, a minimal GSI and photoperiod (Barber and Blake, 2006; Paulet et al., 1997; Saout et al., 1999). Sharp decreases

Table 2

Initial value calculation of state variables in the DEB model of $P$. maximus.

\begin{tabular}{ll}
\hline$L_{i}$ & Observed measurements in the \\
$W_{i}$ & first sampling of the year \\
$V_{i}=\left(L_{i} \delta_{, \varkappa}\right)^{3}$ & \\
$E_{i}=\frac{\left\{\dot{A}_{A m}\right\}}{v} V_{i}$ & \\
$E_{R i}=\left(W_{i}-V_{i} k_{w}-\left\{E_{i} \frac{w_{E}}{\mu_{E}}\right\}\right)\left(\frac{\mu_{E}}{w_{E}}\right)$ & \\
$E_{H i}=E_{H}^{p}$ & \\
\hline
\end{tabular}

observed in measured GSI can be correlated to spawning events. The model was then calibrated to fit GSI observations by taking into account the influence of these forcing variables. The first spawning event of the year in the Bay of Brest is usually synchronous with the first spring bloom (Paulet et al., 1997), thus a threshold in food density was set at $3 \cdot$. $10^{5}$ cells $\cdot \mathrm{L}^{-1}$ (average value corresponding to a substantial resumption of primary production in spring) under which no spawning is possible. As for many bivalve species, temperature has a crucial influence not only on gametogenesis but also on the releasing of gametes. We decided to apply the day-degree concept as a trigger for spawning. Once the seawater has reached a threshold of $12{ }^{\circ} \mathrm{C}$, daily cumulative degrees above this limit were counted and a value of 75 degree-days was found to be required to reach a condition ready for spawning. Then, a minimum GSI of 7 was put at the third trigger for spawning, accounting for a minimal advancement in gametogenesis. The reproduction buffer was then half emptied and the degree-day counter reset. The last parameter, the photoperiod, is a key parameter that blocks the release of gamete so that after the fall equinox no spawning is ever possible (Devauchelle and Mingant, 1991; Duinker et al., 1999; Saout et al., 1999).

\section{Results}

\subsection{DEB parameter estimates}

The DEB parameters estimated for $P$. maximus through the covariation method are presented in Table 3. The overall goodness of fit of model prediction to data on the great scallop's life history traits (Table 4) was evaluated at 8.72 over 10 , with fit $=10 \times(1-$ mre). The only pattern not very well captured is the age at metamorphosis, known to be between 20 and 30 days and which is estimated in our model at about 10 days. Another evidence that there is a satisfactory correspondence between the simulations and the observations is to use a full life-cycle growth data set (Fig. 5), which shows the good prediction of the model. Primary DEB parameters for a given organism always correspond to those of an embryo and for the majority of species do not vary during life span. Nevertheless, some taxa, including $P$. maximus, experience a metabolic acceleration after metamorphosis causing a change in the value of some parameters. The maximum surface-specific assimilation rate $\left\{\dot{p}_{A m}\right\}$ and the energy conductance $\dot{v}$ would respectively increase to $282 \mathrm{~J} \cdot \mathrm{d}^{-1} \cdot \mathrm{cm}^{-2}$ and $0.063 \mathrm{~cm} \cdot \mathrm{d}^{-1}$ at this stage transition. As three-year-old individuals are modeled here, values after metamorphosis have been used for the following simulations. 
Table 3

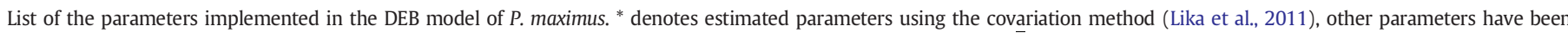
calculated or fixed.

\begin{tabular}{|c|c|c|c|}
\hline Description & Symbol & Value & Unit \\
\hline \multicolumn{4}{|l|}{ Feeding process } \\
\hline Number of moles per one $X$-type food particle & $M_{X}$ & $1.05 \cdot 10^{-10}$ & mol \\
\hline Number of moles per one $Y$-type food particle & $M_{Y}$ & $2.49 \cdot 10^{-9}$ & mol \\
\hline Maximum specific filtration rate of $X$-type particle & $F_{X} m$ & $25-100$ & $1 \cdot \mathrm{d}^{-1} \cdot \mathrm{cm}^{2}$ \\
\hline Maximum specific filtration rate of $Y$-type particle & $F_{Y} m$ & $2-4$ & $1 \cdot \mathrm{d}^{-1} \cdot \mathrm{cm}^{2}$ \\
\hline Binding rate of $X$-type particle & $b_{X Y}$ & $=F_{X} m$ & $1 \cdot \mathrm{d}^{-1} \cdot \mathrm{cm}^{2}$ \\
\hline Binding rate of $Y$-type particle & $\dot{b}_{Y X}$ & 0 & $1 \cdot \mathrm{d}^{-1} \cdot \mathrm{cm}^{2}$ \\
\hline Yield of reserve on $X$-type particle & $y_{E X}$ & 0.7 & $\mathrm{~mol} / \mathrm{mol}$ \\
\hline Yield of reserve on $Y$-type particle & $y_{E Y}$ & 0.4 & $\mathrm{~mol} / \mathrm{mol}$ \\
\hline \multicolumn{4}{|l|}{ Primary parameters } \\
\hline Shape coefficient ${ }^{*}$ & $\delta_{\mathscr{L}}$ & 0.36 & - \\
\hline Fraction of mobilized reserve allocated to soma* & $\kappa$ & 0.86 & - \\
\hline Fraction of reproduction energy fixed in eggs ${ }^{*}$ & $\kappa_{R}$ & 0.95 & - \\
\hline Energy conductance ${ }^{*}$ & $\dot{v}$ & 0.021 & $\mathrm{~cm} \cdot \mathrm{d}^{-1}$ \\
\hline Volume-specific maintenance costs ${ }^{*}$ & {$\left[\dot{p}_{M}\right]$} & 33.52 & $\mathrm{~J} \cdot \mathrm{cm}^{-3}$ \\
\hline Volume-specific costs for structure ${ }^{*}$ & {$\left[E_{G}\right]$} & 2959 & $\mathrm{~J} \cdot \mathrm{cm}^{-3}$ \\
\hline Maximum surface-specific assimilation rate ${ }^{*}$ & $\left\{\dot{p}_{A m}\right\}$ & 94 & $\mathrm{~J} \cdot \mathrm{d}^{-1} \cdot \mathrm{cm}^{-2}$ \\
\hline Maturity maintenance coefficient & $k_{J}$ & 0.002 & $1 \cdot \mathrm{d}^{-1}$ \\
\hline Maturity at birth ${ }^{*}$ & $E_{H}^{b}$ & 0.00028 & $\mathrm{~J}$ \\
\hline Maturity at metamorphosis ${ }^{*}$ & $E_{H}^{m}$ & 0.0078 & $\mathrm{~J}$ \\
\hline Maturity at puberty ${ }^{*}$ & $E_{H}^{p}$ & 3000 & $\mathrm{~J}$ \\
\hline \multicolumn{4}{|l|}{ Compound parameters } \\
\hline Maximum reserve density & {$\left[E_{m}\right]$} & 4483 & $\mathrm{~J} \cdot \mathrm{cm}^{-3}$ \\
\hline Chemical potential of reserve & $\mu_{E}$ & 474,400 & $\mathrm{~J} \cdot \mathrm{mol}^{-1}$ \\
\hline Molecular weight of reserve & $w_{E}$ & 23.9 & $\mathrm{~g} \cdot \mathrm{mol}^{-1}$ \\
\hline Wet weight to Dry weight ratio & $d_{V d}$ & 0.12 & - \\
\hline \multicolumn{4}{|l|}{ Arrhenius temperature } \\
\hline Reference temperature (arbitrary) & $T_{1}$ & 293 & $\mathrm{~K}$ \\
\hline Arrhenius temperature & $T_{A}$ & 8990 & $\mathrm{~K}$ \\
\hline Lower boundary of tolerance range & $T_{L}$ & 273 & $\mathrm{~K}$ \\
\hline Rate of decrease at lower boundary & $T_{A L}$ & 50,000 & $\mathrm{~K}$ \\
\hline
\end{tabular}

\subsection{Environmental forcing variables}

Temperature monitored during a study period of six years follows a rather constant annual cycle (Fig. 4) with common winter values between 8 and 12 from December to February and from 15 to 19 during summer (July to September). Noticeable peaks occurred in summer 2001 reaching a temperature of 19.7 as well as sharp drops until 8.4 during January 2003. POM concentration in the water column is very variable and no clear pattern is identified during the year. Still,

\section{Table 4}

Compilation of life-cycle data from the literature used to estimate the model parameters, using the covariation method of Lika et al. (2011). Values predicted from the estimated parameters are also presented for comparison. Literature references: [1] Gruffydd and Beaumont (1972), [2] Paulet et al. (1997), [3] Mason (1957), [4] Pazos et al. (1997), [5] Chauvaud et al. (1998), [6] Faure (1956), [7] Samain et al. (1986), [8] Christophersen (2000), [9] Paulet and Fifas (1989), [10] Paulet et al. (1997).

\begin{tabular}{|c|c|c|c|}
\hline Data & Literature value & Predicted value & Reference \\
\hline Age at birth & $2 \mathrm{~d}$ & $1.795 \mathrm{~d}$ & [1] \\
\hline Age at metamorphosis & $25 \mathrm{~d}$ & $9.563 \mathrm{~d}$ & {$[1],[2]$} \\
\hline Age at puberty & $\begin{array}{l}\text { During the } \\
\text { second year }\end{array}$ & $464.3 \mathrm{~d}$ & [1], [3], [4], [5] \\
\hline Physical length at birth & $0.008 \mathrm{~cm}$ & $0.007313 \mathrm{~cm}$ & {$[1],[2]$} \\
\hline $\begin{array}{l}\text { Physical length at } \\
\text { metamorphosis }\end{array}$ & $0.024 \mathrm{~cm}$ & $0.02867 \mathrm{~cm}$ & {$[1],[2],[5]$} \\
\hline Physical length at puberty & $4 \mathrm{~cm}$ & $4.426 \mathrm{~cm}$ & {$[1],[5]$} \\
\hline Ultimate physical length & $12 \mathrm{~cm}$ & $11.9 \mathrm{~cm}$ & [6] \\
\hline Dry weight at birth & $1 \cdot 10^{-7} \mathrm{~g}$ & $1.452 \cdot 10^{-7} \mathrm{~g}$ & [7] \\
\hline $\begin{array}{l}\text { Dry weight at } \\
\text { metamorphosis }\end{array}$ & $3 \cdot 10^{-6} \mathrm{~g}$ & $4.030 \cdot 10^{-6} \mathrm{~g}$ & [8] \\
\hline Dry weight at puberty & $1 \mathrm{~g}$ & $1.022 \mathrm{~g}$ & $\begin{array}{l}\text { Chauvaud, pers. } \\
\text { com. }\end{array}$ \\
\hline Ultimate dry weight & $20 \mathrm{~g}$ & $19.85 \mathrm{~g}$ & {$[6]$} \\
\hline Maximum reprod rate & $\begin{array}{l}5.753 \cdot 10^{4} \text { eggs } \\
\text { per spawning }\end{array}$ & $4.227 \cdot 10^{4}$ & [10] \\
\hline
\end{tabular}

tremendous peaks can be seen in May of the years 1998, 2001 and 2003 with values up to almost $8 \cdot 10^{6}$ particles per liter, contrasting with the range of variation observed during the rest of the year (between 1 and $3 \cdot 10^{6}$ particles per liter). The curve presented here is the result of the deduction of algal cell counting from the total POM measured by the SOMLIT station, thus strong decreases are also observable when phytoplankton blooms occur (e.g. in June, July and December 2000 or in August 2003). Finally, Fig. 4 shows a relatively high inter- and intra-annual variability in the counting of algal cells along the studied period. The lowest values are recorded in winter with values under

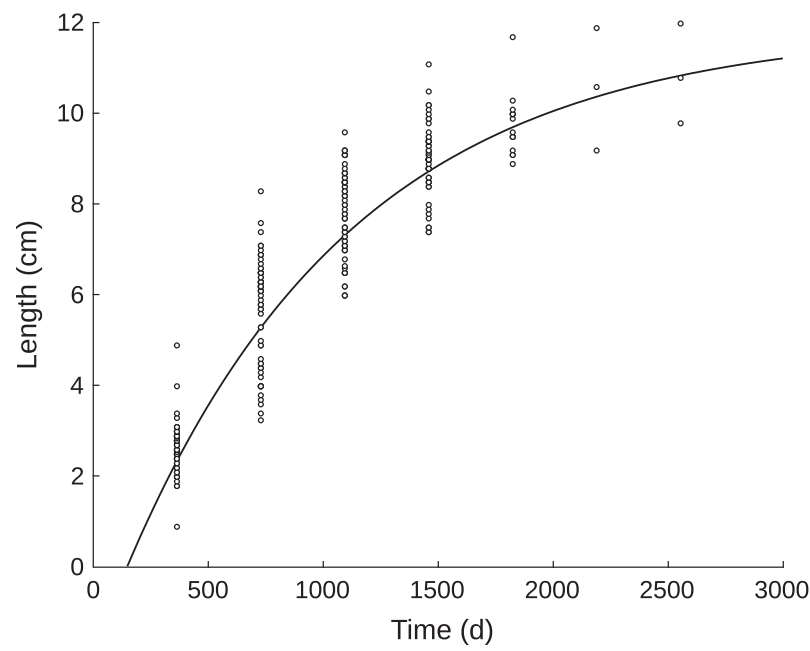

Fig. 5. Simulation of P. maximus shell length over a full life-cycle using the primary parameters of the DEB model (dark line). Dots are a collection of shell length data collected over decades in the bay of Brest and archived in the EVECOS time series (EVECOS database provided by “Observatoire Marin de l'IUEM, INSU, Plouzané”). 


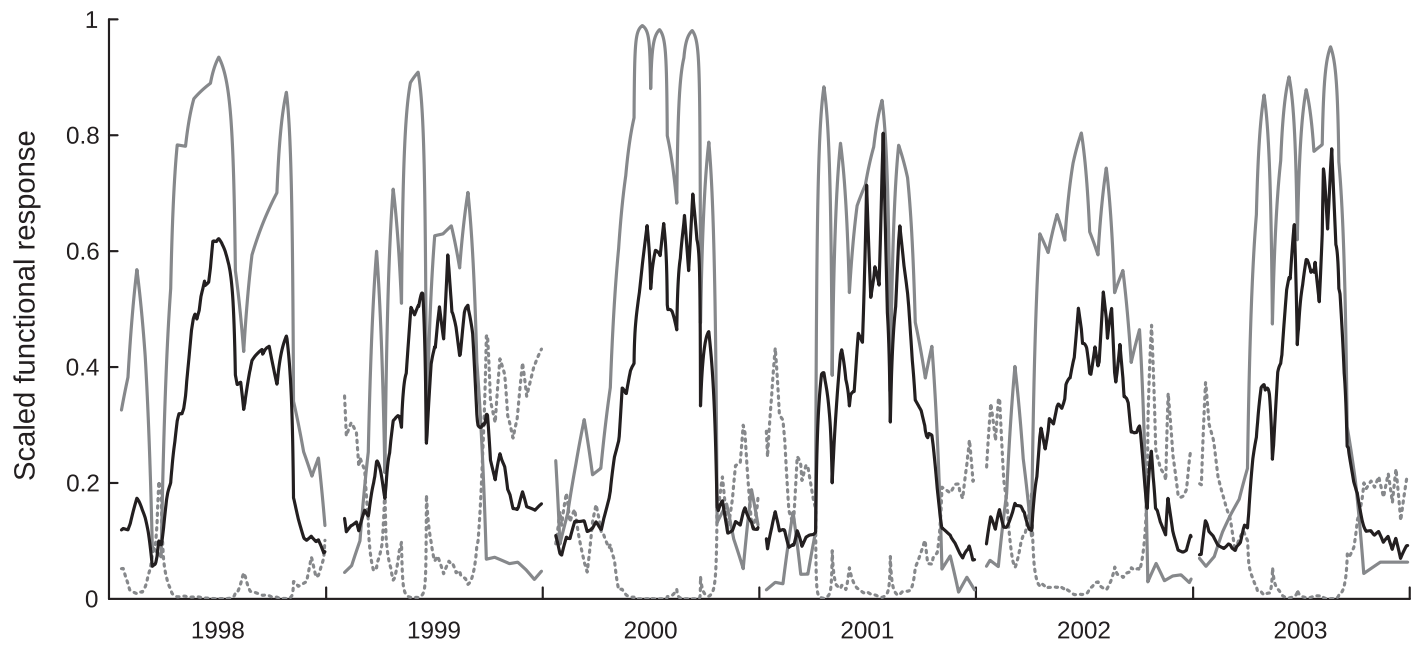

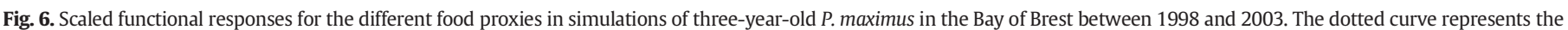

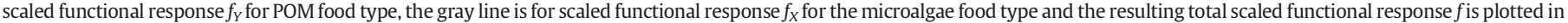
dark line.

$10^{4}$ every year and the first bloom appears in a very irregular way. Indeed, in 1998, 2001 and 2002 the first phytoplanktonic bloom event occurred in late February-early March whereas in other years it is delayed and only occurs between mid-April and June (in 2000). Another interesting feature is the yearly average of phytoplankton cells concentration, allowing to distinguish highly productive years from unfruitful ones. It appears that 2002 would therefore have been the worst year with only 143,759 cells $\cdot \mathrm{L}^{-1}$ followed by 1999 and 2003 with respectively 239,305 and 262,260 cells $\cdot \mathrm{L}^{-1}$. Then come the more productive years, 2001, 1998 with respectively 392,150 and 439,278 cells $\cdot \mathrm{L}^{-1}$ and eventually, 2000, the most productive year in terms of phytoplankton cell concentration with about 504,592 cells $\cdot \mathrm{L}^{-1}$.

\subsection{Feeding and food sources}

Fig. 6 shows the functional responses $f_{X}$ and $f_{Y}$, of the two food types respectively and the total $f$ as the overall functional response of the scallop to the food supply. It pictures the alternation between the two food types available according to the period of the year. Phytoplanktonic concentration is very low until the end of winter and after mid fall (Fig. 4)
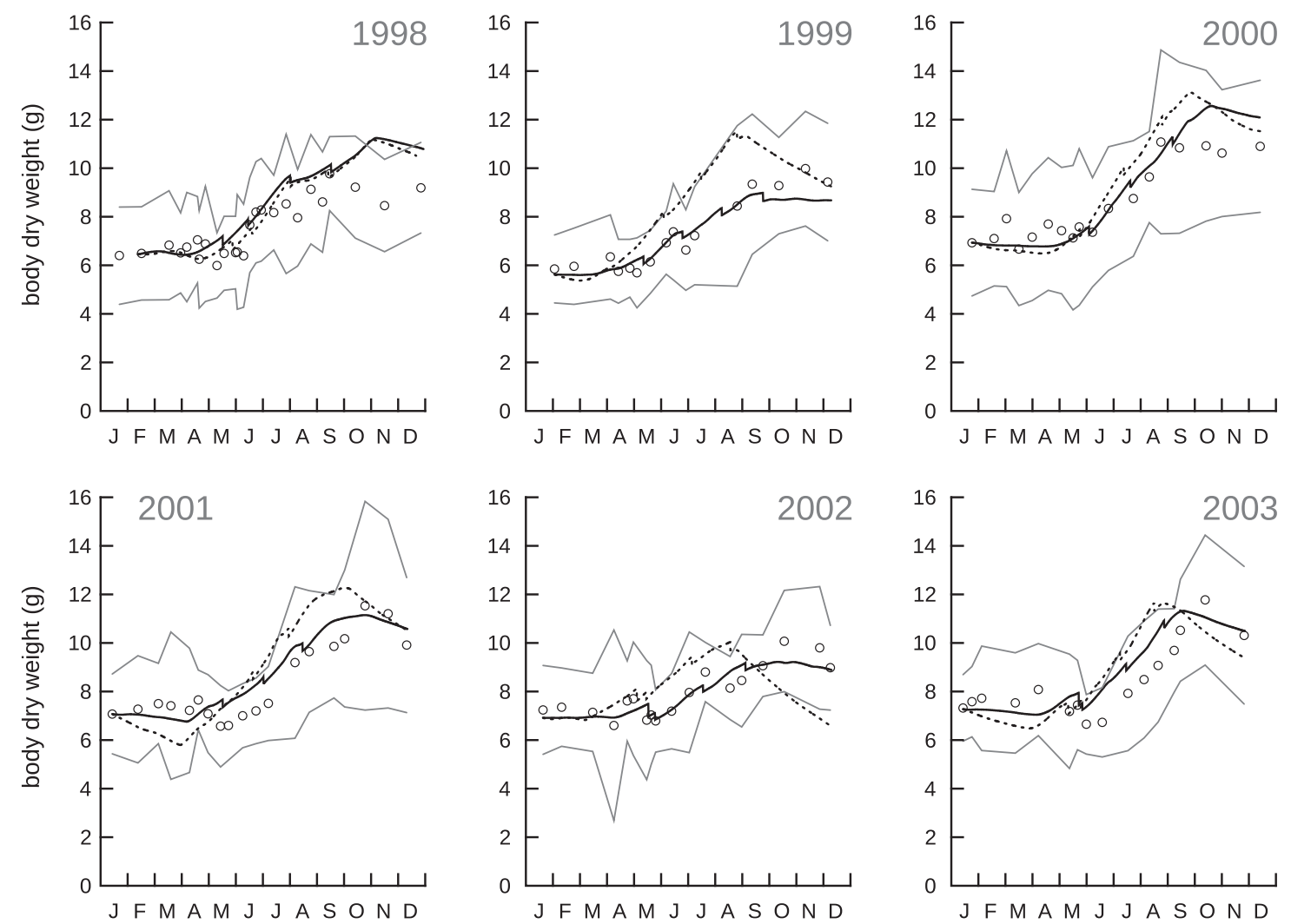

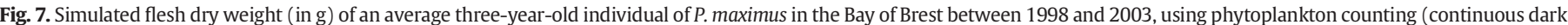

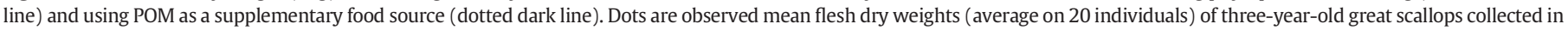

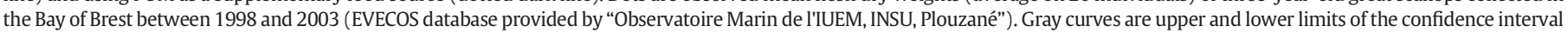
( $p=0.05$ ) for measurements. 
whereas POM is present almost all the time. This results into a more elevated $f_{Y}$ at the beginning and at the end of the year which falls under 0.1 the rest of time, when phytoplankton cells are more present. The functional response to POM concentration never reaches levels above 0.5 and is mostly fluctuating between 0 and 0.4 . In 1998, it was never over 0.2 and reached a maximum in October 2002. On the contrary, the $f_{X}$ reaches high values almost all years during phytoplanktonic blooms, from 0.8 in June 2002 to May 0.99 in 2000 but is almost null in winter.

The two calibrated parameters in the simulations using the preference module were the maximum specific filtration rates $F_{X m}$ and $F_{Y m}$. They account for the amount of water cleared when food particles of each type are in the environment. $F_{X m}$ varied between $50 \mathrm{~L} \cdot \mathrm{d}^{-1} \cdot \mathrm{cm}^{2}$, in 2001 and $100 \mathrm{~L} \cdot \mathrm{d}^{-1} \cdot \mathrm{cm}^{2}$, in 2000 and $F_{Y m}$ from $2 \mathrm{~L} \cdot \mathrm{d}^{-1} \cdot \mathrm{cm}^{2}$, in 1998 to $4 \mathrm{~L} \cdot \mathrm{d}^{-1} \cdot \mathrm{cm}^{2}$, in 1999 . Most of the $F_{X m}$ were set around $50 \mathrm{~L} \cdot \mathrm{d}^{-1} \cdot \mathrm{cm}^{2}$ and most of the $F_{Y m}$ around $2 \mathrm{~L} \cdot \mathrm{d}^{-1} \cdot \mathrm{cm}^{2}$. No clear relationship is found between values of $F_{X m}$ and $F_{Y m}$ and the phytoplankton or POM concentration in the water. As for the value of $X_{K}$ in the simulations using only phytoplankton, it ranged from $40,000 \mathrm{H} \cdot \mathrm{L}^{-1}$ in 2000 to $160,000 \# \cdot \mathrm{L}^{-1}$ in 1998 and 2001.

\subsection{Model simulation}

Several physiological processes and life traits of three-year-old scallops were simulated using the DEB model from 1998 to 2003 in the Bay of Brest. Simulations of dry flesh weight are presented in Fig. 7. The model successfully captured the variations of dry weight along the seasons. Modeled weights using only one food proxy are less accurate than weight estimations resulting from the two-food-type assimilation module. The general pattern observed when the model is fed with one food source is an over-estimation in spring and autumn whereas at the end of the year, simulations often decrease too much compared to observations. Now concerning the simulations when both cell counting and
POM are taken into account, a slight over-estimation in winter 1998 and 2000 is to be noticed, and a small under-estimation during winter 1999 too. The brutal weight losses that can be seen along the simulations account for spawning events which seem to have a rather low impact on the total body dry weight. Flesh growth is variable from one year to another but very similar between observed and simulated data: during year 2000, scallop dry weight increased by $4 \mathrm{~g}$ dry mass (5 $\mathrm{g}$ according to simulations) whereas in 2002 the gain in mass was only of $1.7 \mathrm{~g}$ dry weight (1.8 $\mathrm{g}$ according to simulations). The highest discrepancy between observed and simulated data is reached in 1998 as the model predicts a final dry weight $1.6 \mathrm{~g}$ heavier than the observations. That year, during the last months of growth, the observed weight loss (down to $8.5 \mathrm{~g}$ ) was not reproduced as the model predicted a rather strong peak (11.2 g) in November. At the end of winter, scallops sometimes do not have enough energy in reserves and maintenance has to be paid from structural volume. The flesh dry weight can then loose few milligrams as it is observed between January and March 2001 and 2003 with a loss of 0.3 and $0.2 \mathrm{~g}$ dry weight respectively. The acceleration of growth rate from spring to mid-autumn is well reproduced every year, after which a decrease in the first months of winter is well simulated.

Shell growth was investigated in two complementary ways: (1) by examining the daily shell growth rate and (2) by looking at the cumulated growth in length. Fig. 8 shows the simulated DSGR for the six studied years. The observed data correspond to the cumulated average of DSGR measured on a sample of 10 individuals of the three-year age cohort of the studied year. The lowest measured DSGR was $20.3 \mu \mathrm{m} \cdot \mathrm{d}^{-1}$ (in 2001) and the highest was $156.2 \mu \mathrm{m} \cdot \mathrm{d}^{-1}$ (in 2003) whereas the simulated DSGR ranges from 1 to $91.7 \mu \mathrm{m} \cdot \mathrm{d}^{-1}$. Peaks of growth rate are hardly predicted but the simulated DSGR is still in the order of magnitude of the observations, except in 1998 and 2002 where a low growth is observed. Regarding the duration of the growing season, the simulations are in accordance with the observations. The resumption of
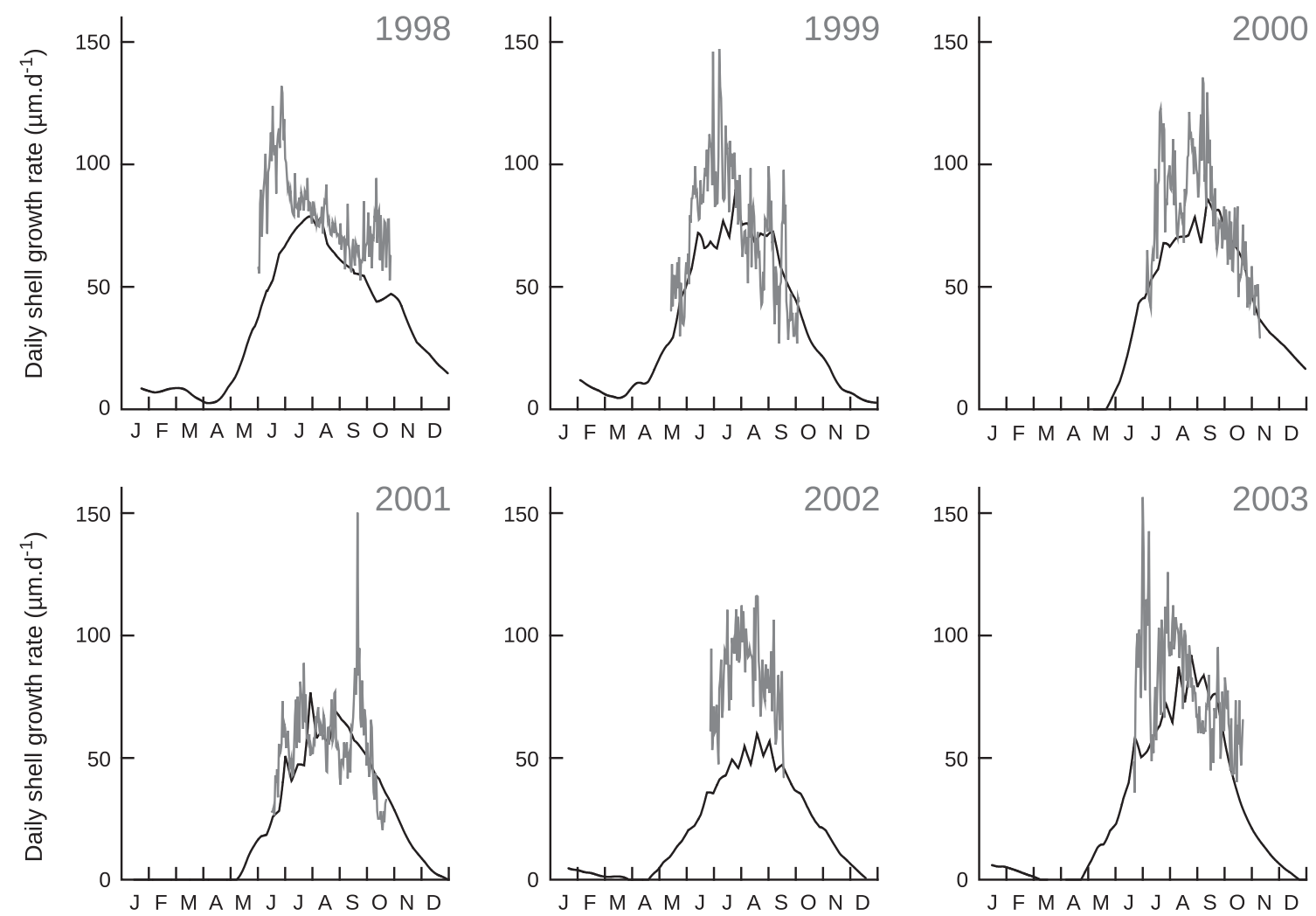

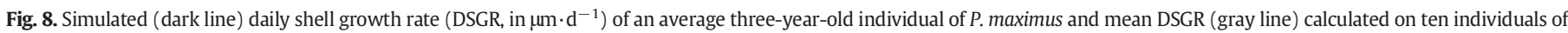
three-year-old great scallops collected in the Bay of Brest between 1998 and 2003 (EVECOS database provided by "Observatoire Marin de l'IUEM, INSU, Plouzané"). 

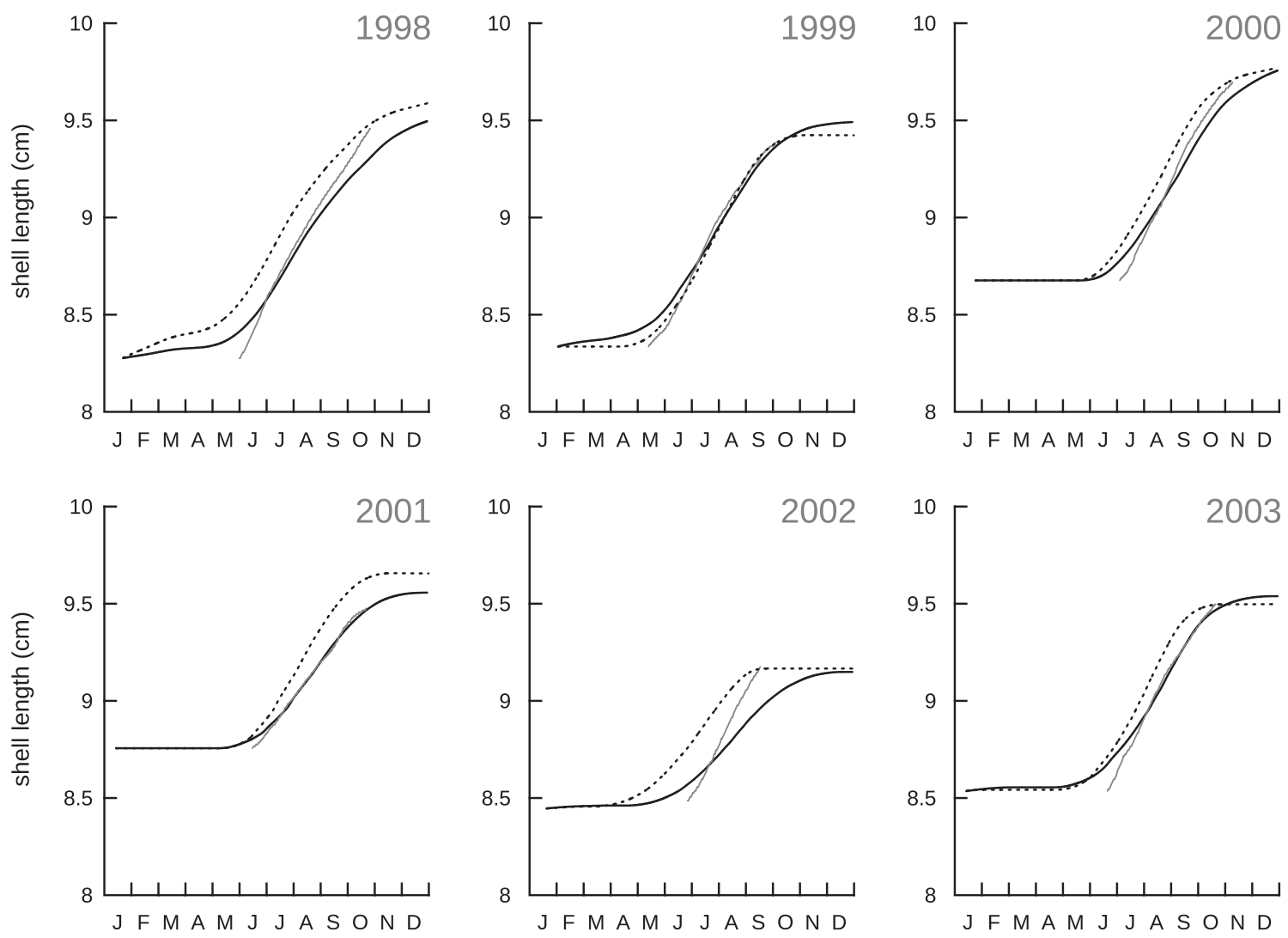

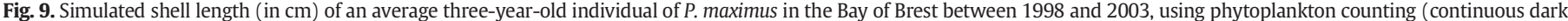

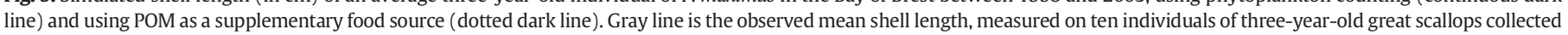
in the Bay of Brest between 1998 and 2003 (EVECOS database provided by “Observatoire Marin de l'IUEM, INSU, Plouzané”).

shell growth is precisely captured by the model with an average time lag less than a week. An odd feature is observed during the first months of winter 1998, 1999, 2002 and 2003 where the model predicts a tiny growth in length $\left(<10 \mu \mathrm{m} \mathrm{d}^{-1}\right)$ at a moment of dormancy for P. maximus.

The shell lengths presented in Fig. 9 correspond to the cumulated growth in length. Simulated growth can here be compared to the observations with an emphasis on the final size of the animal at the end of the growing season. Here again simulated shell length using phytoplankton only is less relevant than those using algae plus POM. Growth always seems to start earlier in simulated data than in observed ones, which relates to the precocious low DSGR observed previously at the beginning of the year (see Fig. 8) and not taken into account in the observed data. The total increase in shell length (the shell length produced during the year) is very well modeled, with a slightly longer distance in the predicted data (still less than $100 \mu \mathrm{m}$ ), ranging from $0.05 \mathrm{~mm}$ in 2003 to $1.5 \mathrm{~mm}$ in 1999 or 2001. Except for the year 2002, the slope of the predicted growth curve is extremely similar to the observed one.

The last biological trait studied is the gonado-somatic index (GSI), shown in Fig. 10. P. maximus from the Bay of Brest are known to spawn in a very variable way, regarding the intensity, the number and the timing of spawning events between individuals and years. Apart from a slight over-estimation at the end of years 1998 and 2001, the ratio of reproduction buffer over structure is rather well described by the model when the two food descriptors are taken into account. If only phytoplankton is considered, more decreasing periods are observed like in spring 1999, 2001 or autumn 2002, which does not match the observed data at these moments. The timing of the first spawning event is accurately reproduced in the simulation (a little less when using only one food proxy). The spawning efficiency parameter set at 0.5 , meaning that the gonad is half-flushed during spawning, seems to be a relevant value since the simulated GSI does not fall below the lower bound observed.

The model response was also tested by the simulation of an average individual from its birth until several years of growth along the study period. Fig. 11 presents the growth curve of a great scallop born in June 1998 that lived five years in the Bay of Brest (environmental variables were the same as those used in previous simulations). Predictions made by the model are very realistic, producing a five-year-old scallop of $11 \mathrm{~cm}$ with a very low growth rate at this age, which closely matches observations. Finally, the last property of the model was highlighted by plotting DSGR data both observed and simulated against environmental variables to look at the effects of forcing parameters on growth. Fig. 12 shows for years 1999 and 2001 that simulated DSGR is strongly forced by bottom temperature. Functional response and thus food availability have minor effect on the modeled growth while it appears to be more determining when looking at the measured DSGR. This particularly holds true when the feeding response shows sharp decreases like in June 1999 or late August 2001.

\section{Discussion}

\subsection{Modeling the life-cycle of P. maximus}

In this study, we used DEB theory to build a mechanistic bioenergetic model for P. maximus in the Bay of Brest, including a detailed formulation of the ingestion and food handling processes through the SU concept. The set of estimated parameters allowed us to reproduce the growth of an average great scallop individual during its entire lifecycle with a satisfying accuracy (Fig. 5). The age at metamorphosis was the only life trait that did not fit very well (Table 4), despite the addition of the acceleration module (Kooijman et al., 2011) to the standard 

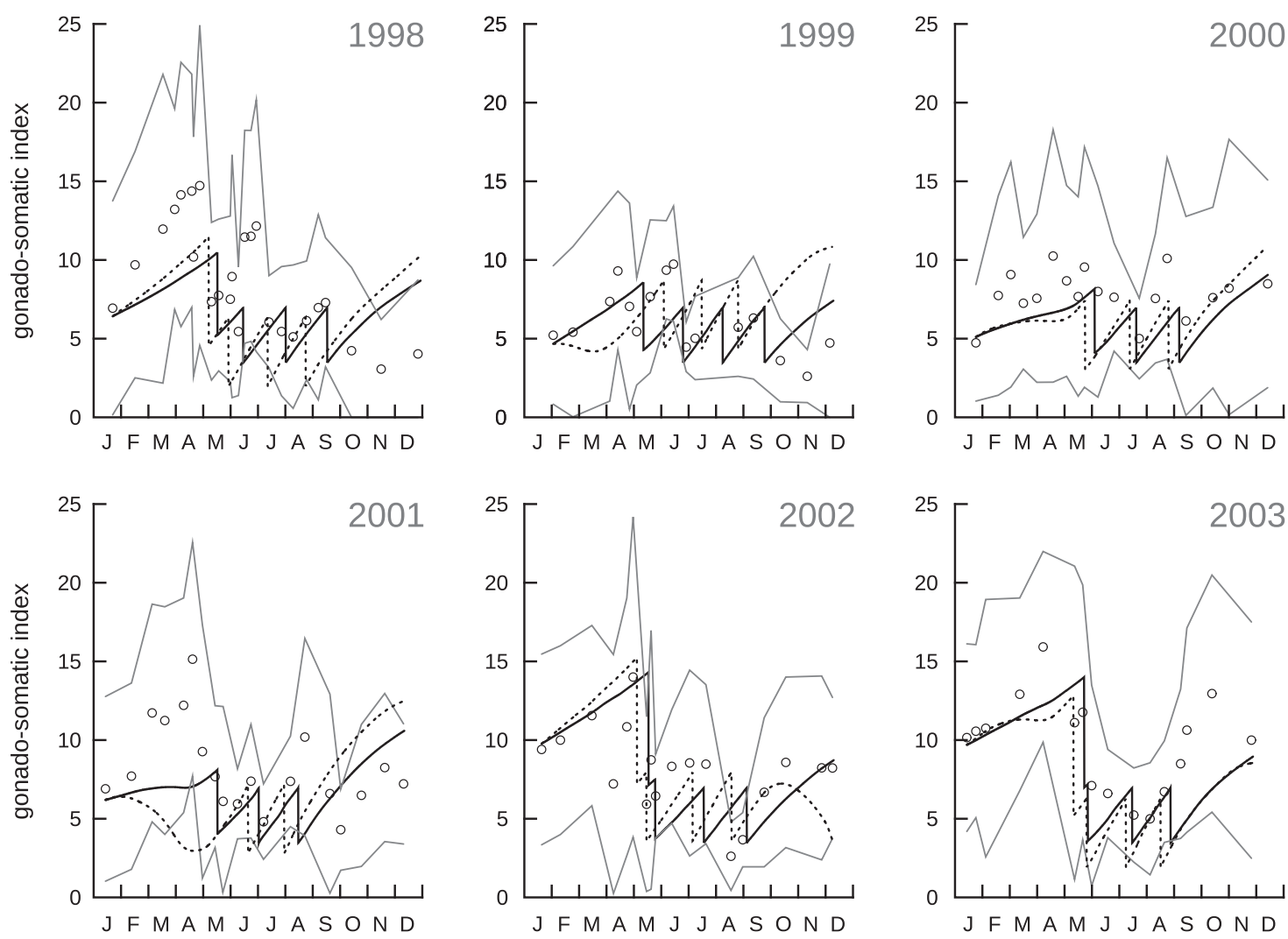

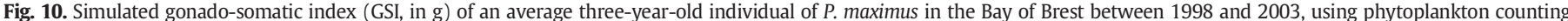

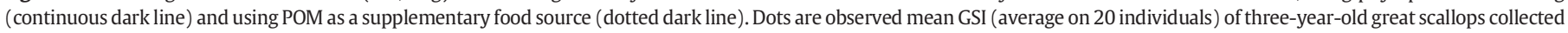

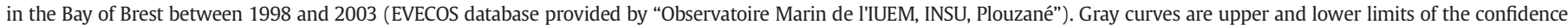
interval $(p=0.05)$ for measurements.

DEB model. It may be linked to the low accuracy of the determination of age, size and weight at sexual maturity. This maturity level is reported through the literature to be reached during the second year of life (Chauvaud et al., 1998; Mason, 1957; Pazos et al., 1997). A more precise knowledge of the timing of this critical life trait would certainly allow to capture more efficiently the characteristics of other development stages.

The model was tested in the well studied environment of the Bay of Brest during six years of environmental monitoring and scallop sampling. Model predictions sometimes showed less good correspondence with measured data, like in 2002 when DSGR was hardly simulated, or at the end of the year 1998 when an over-estimation of dry weight is detected. It has to be noted that daily increments under $50 \mu \mathrm{m}$ are very difficult to measure under binocular magnifier which tends to reduce the observed number of truly formed increments and the minimal size of striae observed. The model sometimes predicted slightly longer shell height which can easily be explained by the fact that archived shells have been manipulated many times causing

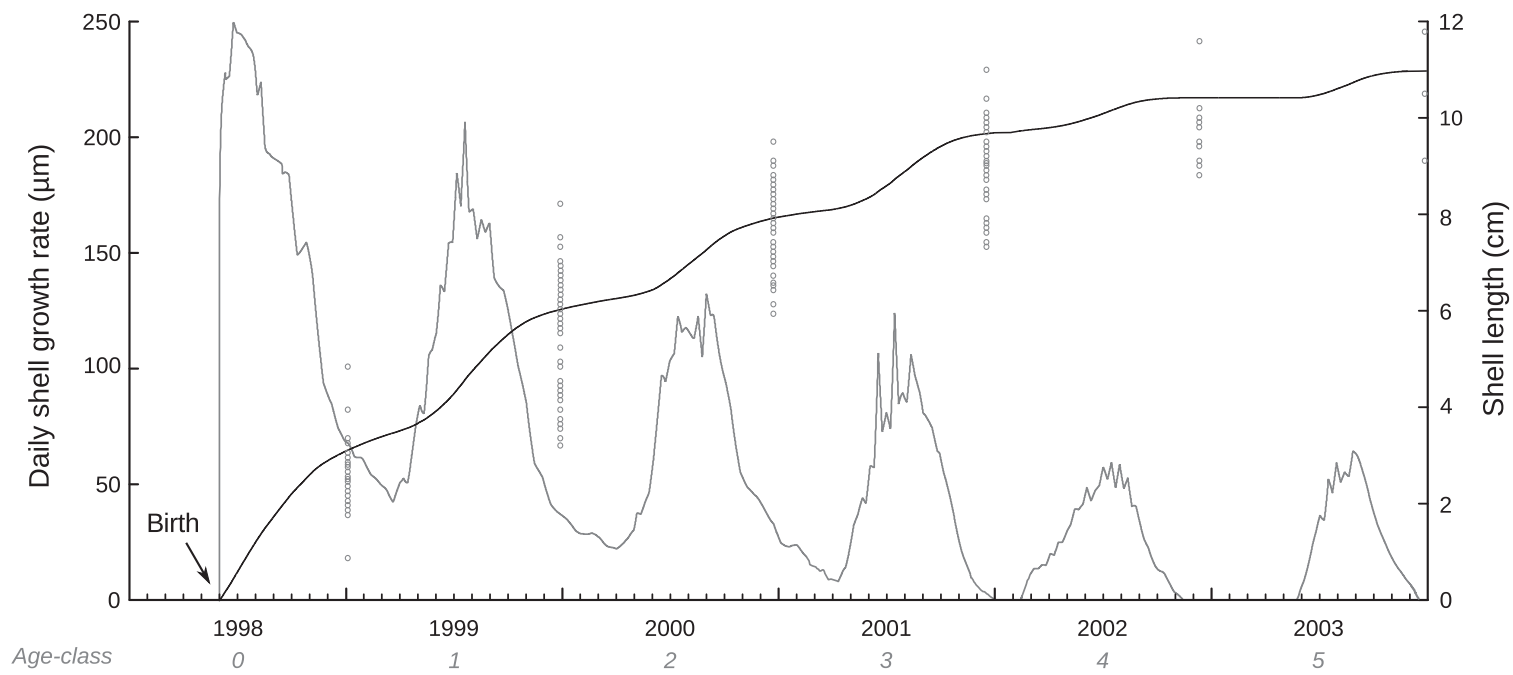

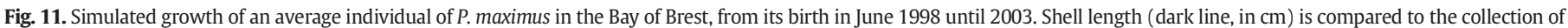

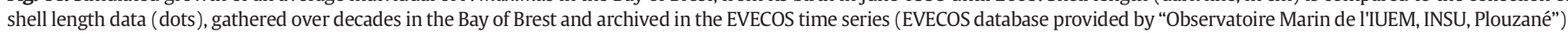
Daily shell growth rate (in $\mu \mathrm{m} \cdot \mathrm{d}^{-1}$ ) is the gray line. Environmental variables (temperature and food markers) are the same as those used in simulations of three-year-old scallops. 

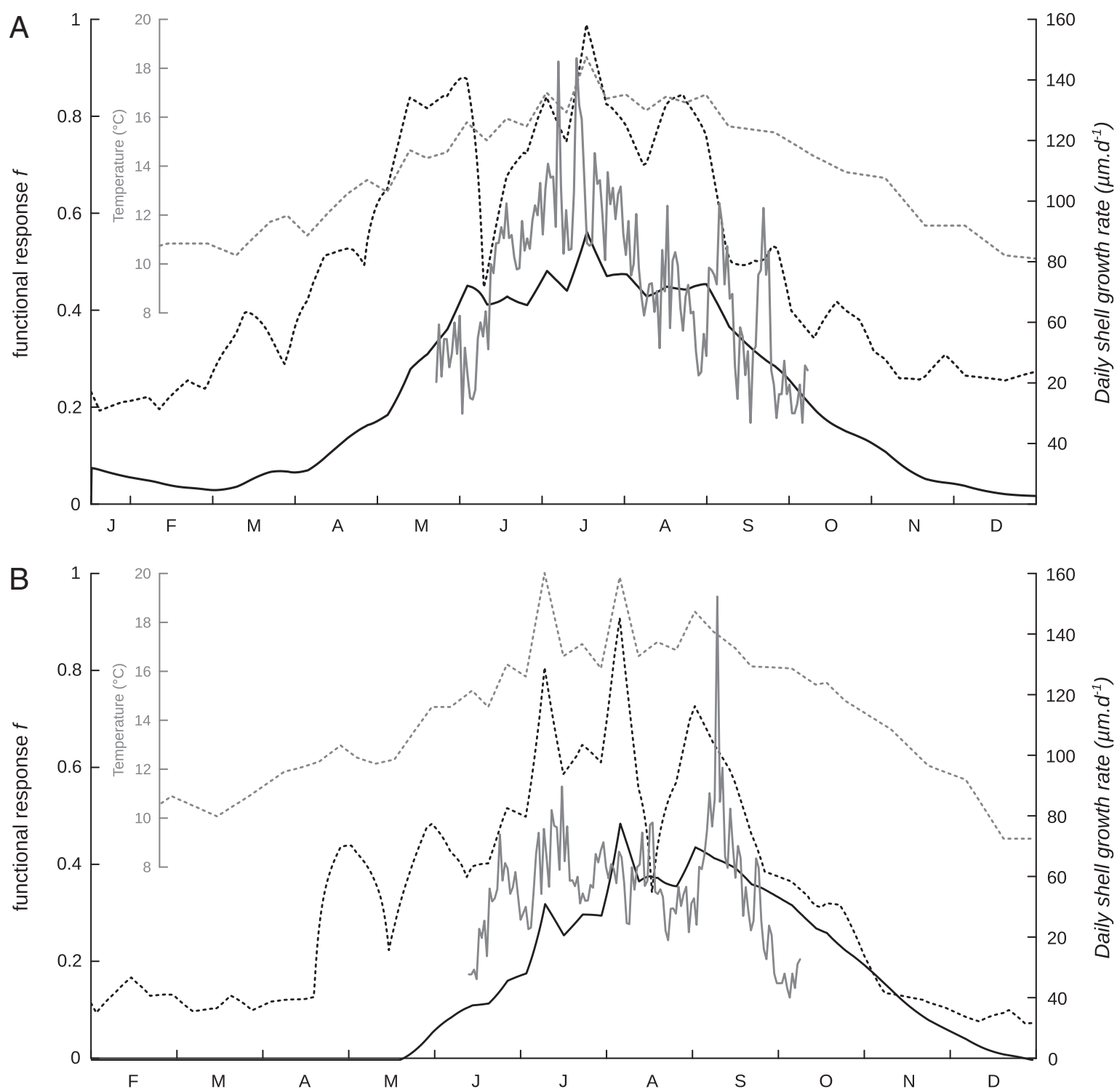

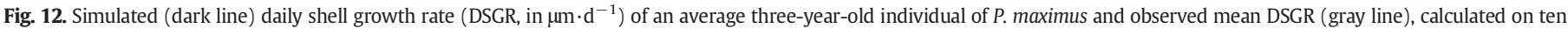

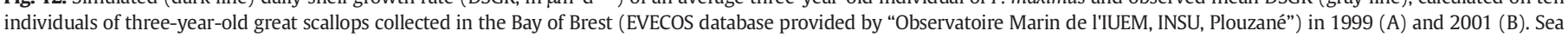
bottom temperature (gray dotted line, in degree Celsius) and the total functional response $f$ (dark dotted line) are also plotted.

damages to the ventral margin of the shell, i.e. the latest increments formed, which can have been abraded. But in a general way, the various physiological traits simulated in three-year-old individuals in the Bay of Brest were very similar to the observations made on wild population during this period.

All simulations presented here were made over one year and for individuals that belong to three-year age cohort, which correspond to an age between 2.5 and 3.5 years old. An interesting question is how the model behaves in the long term, when scallops are grown from the egg to an advanced age. Fig. 11 shows that when the simulated animal reaches three years old in 2001 it can be compared to observations made this year on scallops of the same year-class (Figs. 8 and 9). Here again we see that this long term simulation is in accordance with observations.

\subsection{Growth and feeding}

An interesting pattern is that simulated DSGR is strongly impacted by bottom temperature, as shown in Fig. 12. This is in accordance with works of Chauvaud et al. (1998) who highlighted the major role of thermal conditions in normal growth variations (95\% of the variability explained by this factor). It is also in accordance with the DEB theory and more generally with the Arrhenius relationship. This law states that all physiological rates, including the energy flux allocation from reserve to shell production (i.e. structure), are impacted by temperature. Concerning growth anomalies and short term variations in shell growth, it has been established that food was one the most triggering factor (Chauvaud et al., 1998; Lorrain et al., 2000). This pattern was not very well captured by the model compared to measured DSGR (Fig. 12). In 1999, scallops show a daily growth divided into three periods: (1) a low start around $50 \mu \mathrm{m}$ per day during few weeks, (2) then a sharp increase to more elevated values close to $90 \mu \mathrm{m}$ per day with two peaks reaching $140 \mu \mathrm{m}$ per day and (3) a progressive decrease punctuated with small and short peaks until a definitive stop in early October. The same profile was observed on one-year-old scallops by Lorrain et al. (2000) for the same year. On the contrary, the model predicts a rather smoother growth along the growing period (which has still the same duration and timing), with a DSGR rapidly reaching a plateau around 
$70 \mu \mathrm{m}$ and starting to decrease two months later than the observations but at a faster rhythm.

One objective of this work was to test the hypothesis of a selective ingestion of $P$. maximus between two substrates. When looking at the functional responses of the modeled individuals (Fig. 6), we see that $f_{X}$ reaches high values almost all years during phytoplanktonic blooms. On the contrary, $f_{Y}$ is rather low all along the year, which tends to confirm our guess. The maximum specific filtration rate for phytoplankton cells $\left(F_{X m}\right)$, which was calibrated to fit the observed data, varied between 25 and $100 \mathrm{l} \cdot \mathrm{d}^{-1} \cdot \mathrm{cm}^{2}$ respectively. This corresponds to values of $11 \mathrm{l} \cdot \mathrm{h}^{-1}$ and $44 \mathrm{l} \cdot \mathrm{h}^{-1}$ per individual, which is in accordance with literature values (Cranford et al., 2011; Shumway and Parsons, 2006; Strohmeier et al., 2009). On the other hand, $F_{Y m}$ varies at a far more lower level, between 2 and $4 \mathrm{l} \cdot \mathrm{d}^{-1} \cdot \mathrm{cm}^{2}$. This clearly indicates that substrate X (phytoplankton cells) is positively selected compared to substrate Y (rest of POM), which confirms our hypothesis. It is relatively easy to understand this when considering the high energetic quality of fresh phytoplankton cells compared to suspended matter, which includes organic debris (Alber and Valiela, 1996). The use of the POM proxy as a second food source, yet under-selected, shown its benefits compared to simple diet simulations. POM seems to be an additional food source allowing scallops to compensate phytoplankton limitation between algae blooms. Indeed some studies have already shown evidences of organic aggregates and floc assimilation in scallops, although less efficiently than phytoplankton (Alber and Valiela, 1996; MacDonald et al., 2006).

Even if the maximum specific filtration rate is in compliance with already reported data, one can see that its variation range is rather large. Although the model is entirely deterministic, we still face the fact that the filtration rate is obtained by calibration, as it used to be the case with the half-saturation constant in previous DEB models. Possible reasons for such differences among years might rely on the inter-individual variability. Indeed, animals collected at the very same moment and selected in the same year class showed considerable heterogeneity in biometric measurements (see the confidence intervals of observed data in Figs. 7 and 10). Moreover, consequent amounts of inorganic particles from riverine inputs are discharged in the Bay of Brest and could also cause annual variations in the mean filtration rate. Indeed, filtration rates of filter feeding bivalves are negatively impacted by these nonedible particle inputs, which compete with food particles (Kooijman, 2006; Saraiva et al., 2011b. To improve the determinism in the maximum specific filtration rate estimation and avoid calibration steps two conditions are required: 1 ) integrate the effect of non-edible particles via a third substrate for SUs as done by Saraiva et al. (2011b) and 2) include feeding experiment data into the parameter estimation procedure to better determine filtration and ingestion rate parameters.

A recurrent issue in individual bioenergetic modeling is the choice of a good food proxy. Some studies using DEB theory to model bivalve bioenergetics have already raised this problem (Bourlès et al., 2009; Pouvreau et al., 2006; Rosland et al., 2009). Bourlès et al. (2009) tested different types of trophic markers like particulate organic matter, particulate organic carbon, chlorophyll a concentration and phytoplankton enumeration. It came out that chl-a concentration, albeit being easily monitored, was not sufficient to capture all the variations observed in the physiological processes studied. On the other hand, they showed that microalgae expressed in cell number per liter should be considered as a better food marker. This approach worked efficiently for $C$. gigas and also seems to be relevant for P. maximus. Fig. 12 also shows that the simulated ingestion represented by the functional response is in accordance with the observed DSGR, except in early August 2001 when no growth increase is observed whereas the model shows a rather high ingestion.

Deviations between the model and data might be addressed by a better descriptor of the trophic source that would integrate food quality. Indeed, Lorrain et al. (2000) have shown that the DSGR of one-year-old scallops in the Bay of Brest could be negatively impacted by the presence of some phytoplanktonic species such as diatoms Cerataulina pelagica or Rhizosolenia delicatula, responsible of short drops in the daily growth of these animals in early May 1998 and 1999. However, since we used individuals from the three-year age cohort who started their shell growth later in the year due to their age (late May and June respectively), we did not observed such effects. Moreover, DSGR of three-year-old scallops is two times lower than in younger individuals. It is thus difficult to see the variation of ingestion according to food biomass from the DSGR profiles in our study. A perspective to the present study could consist in testing differential ingestion rates for $P$. maximus when the phytoplanktonic biomass is dominated by some algae species during crucial period of the growing season (e.g. when the great scallop is also about to start to reproduce and complete its gamete maturation).

\subsection{Reproduction}

Modeling reproductive activity is not a simple task, especially for $P$. maximus, an asynchronous spawner that only flushes partially its gonad during highly variable spawning events. DEB theory does not specify how to handle reproductive effort in a general way, each species needs a specific implementation. In our model, spawning triggering requires data that are already necessary to run a DEB model (temperature and food) plus a photoperiod sinusoid. It is well known that parameters potentially bringing about gamete release in scallops are numerous, including not only temperature, food availability, and photoperiod but also lunar phase, salinity, dissolved oxygen, $\mathrm{pH}$, mechanical shocks and ectocrines (Barber and Blake, 2006). Therefore, we were motivated to take into account the most recognized factors. The resulted simulated GSI is acceptable as it reproduces the general pattern of gonad dynamics (Fig. 10). The predicted start of gametogenesis in winter matches the observed data, except in 1998 and 2001, where the increase of the simulated index is not as sharp as in the observations. During winter, energy stored in the reproduction buffer $E_{R}$ is not only used to produce gametes but also to meet maintenance requirements if reserves are not sufficient to do so under seasonal starvation. The fact that this energy would be used for two different processes during the same period (Lorrain et al., 2002; Mason, 1957) might explain the general underestimation observed at the beginning of the winter. A study of the biological cycles of $P$. maximus realized by Paulet et al. (1997) brings another look on the mechanisms involved in the compartment dynamics. Paulet and co-workers described the complex evolution of the gonad in relation to somatic tissues along the year. They showed that gametogenesis presented a stop in October and November, another one at the end of the winter and a maximum gametic production period in April and May. This is consistent with our results except for the late autumn stop. As non-emitted gametes during spawning events are resorbed and eliminated during fall, they provide energy to other tissues thanks to atresia (Le Pennec et al., 1991). Exploring this phenomenon in more details could improve the simulation of reproductive effort of $P$. maximus at the end and the beginning of the year (but at the expense of the model simplicity). Eventually, the mismatch between simulated and observed data in early 1998 and 2001 might also suffer from a rather elevated value of $\kappa(0.86)$ compared to other bivalve species such as the Pacific oyster ( 0.45 in van der Veer et al., 2006) or the blue mussel (0.67 in Saraiva et al., 2011a; 0.45 in Rosland et al., 2009).

Bernard et al. (2011) tried to improve the implementation of the reproductive effort in the DEB model of $C$. gigas in relation to environmental conditions. They adopted an approach involving the creation of a new state variable (the gonad structure) plus three additional parameters, while using derivatives of temperature as signals to begin and end the gametogenesis. However, those manipulations did not significantly address the bad fit of simulated gamete releases compared to observed data. Moreover they reported only one spawning event for C. gigas whereas several ones are clearly identified in P. maximus biological cycle, which may reduce the difficulty to accurately simulate it. One of their conclusion was to put more emphasis on the intake of 
energy rather than on the reproductive activity. But finally, when looking at these two studies, one focusing on the reproductive effort modeling and ours on the feeding modeling, results are sensitively the same.

To finish, one step not yet reached by this model is the simulation of the number of gametes emitted. In the current state, our model considers that the flux of reserve $\dot{p}_{k}$ is used either for maturation (when in the juvenile stage) or to fuel the reproduction buffer (after reaching the adult stage) from which gamete production is realized. Modeled reserves in the reproduction buffer are not necessarily used immediately for gamete production. This has a repercussion in the simulation of this index, which can show a too great increase at the end of the year (especially in 1998 and 2001) compared to the field data. This could be explained by two means. First, it is possible that a very late spawning event occurred, outside the generally expected period in this location (from May to July, Paulet et al., 1997). Incidentally, this late spawning would probably not be significant for the population growth, since larvae hatching at this period of the year would hardly survive to bad food condition of autumn. The second possible cause relies on the already invoked atresia hypothesis. This phenomenon is not integrated into the model and would require additional parameters. In order to keep a relatively low complexity level of the model and because this physiological process was already rather well simulated (our estimations are still in the confidence range of the data variability) we did not implemented this pattern into the model.

\subsection{Conclusions and perspectives}

In this study we implemented a DEB model for the great scallop, P. maximus, in the Bay of Brest using the Synthesizing unit concept to model energy acquisition. Primary parameters were obtained by the covariation method for parameter estimation, producing estimates able to reproduce life-cycle history traits with still a slight underestimation of the age at metamorphosis. Various physiological processes such as growth in weight, shell growth or reproductive activity were accurately modeled and successfully matched observation data over a sixyear study. To complete the validation of this model we need to test the set of parameters on another population living in a relatively different environment such as the cold and eutrophic fjords of Norway for instance.

Results of this work showed that assimilation even if well implemented in the model still requires some improvement and a deeper reflection, especially concerning the trophic input. We did not address the issue of the determinism of energy input as the maximum filtration rate still requires a calibration. However we brought tools to develop and improve the way feeding of filter feeders is formalized within DEB theory. Saraiva et al. (2011b) went further deep into the description of filtration, ingestion and assimilation processes in mussels M. edulis. By taking into account silts as another potential substrate for SU, they were able to describe these processes through a DEB model, considering the effect of non-edible particles on energy allocation. As the Bay of Brest receives high riverine inputs from two rivers and underwent a recent invasion by the slipper limpet Crepidula fornicata causing a significant silting up of the bay's sea-floor (Thouzeau et al., 2002), it would be interesting to look at the response of the model when fueled by both organic and inorganic matters.

It has long been suspected that filter feeders and especially $P$. maximus could be able to select algae cell types according to their chemotactile attractiveness, size or shape (Raby et al., 1997; Ward and Shumway, 2004). The state of freshness of phytoplankton cells might also be critical so efforts should be deployed to find food markers able to describe the quality of the trophic resource. Moreover, recent works have reaffirmed through isotopic analysis the presence in $P$. maximus diet of bacteria (Nerot et al., 2012). It must also be interesting to look at this feature but certainly much more difficult to assess the bacterial biomass in the environment.

\section{Acknowledgments}

We would like to thank the "Service d'Observation en Milieu Littoral, INSU-CNRS, Brest" and the REPHY network (PHYtoplankton and PHYcotoxins monitoring NEtwork, Ifremer) for providing the environmental data. The authors also recognize A. Jolivet for the great help in shell growth analysis and the proofreading of this paper. Part of the funding of this work was provided by the COMANCHE program (ANR2010-STRA-010).

\section{References}

Alber, M., Valiela, I., 1996. Utilization of microbial organic aggregates by bay scallops, Argopecten irradians (Lamarck). J. Exp. Mar. Biol. Ecol. 195, 71-89.

Alunno-Bruscia, M., Bourlès, Y., Maurer, D., Robert, S., Mazurié, J., Gangnery, A., Goulletquer, P., Pouvreau, S., 2011. A single bio-energetics growth and reproduction model for the oyster Crassostrea gigas in six Atlantic ecosystems. J. Sea Res. 66, 340-348.

Antoine, L. Garen, P., Lubet, P., 1979. Conséquences sur la maturation et la croissance d'une transplantation de naissain de Pecten maximus (L.). Cahiers de Biologie Marine, 20. Station Biologique de Roscoff, pp. 139-150.

Bachok, Z., Meziane, T., Mfilinge, P.L., Tsuchiya, M., 2009. Fatty acid markers as an indicator for temporal changes in food sources of the bivalve Quidnipagus palatum. Aquat. Ecosyst. Health Manag. 12, 390-400.

Barber, B.J., Blake, N.J., 2006. Reproductive physiology. Scallops: Biology, Ecology and Aquaculture. Developments in aquaculture and fisheries science, vol. 35. Elsevier, pp. 357-416 (chapter 8).

Bayne, B.L., Hawkins, A.J.S., Navarro, E., 1987. Feeding and digestion by the mussel Mytilus edulis L. (Bivalvia: Mollusca) in mixtures of silt and algal cells at low concentrations. J. Exp. Mar. Biol. Ecol. 111, 1-22.

Bernard, I., de Kermoysan, G., Pouvreau, S., 2011. Effect of phytoplankton and temperature on the reproduction of the Pacific oyster Crassostrea gigas: investigation through DEB theory. J. Sea Res. 66, 349-360.

Bourlès, Y., Alunno-Bruscia, M., Pouvreau, S., Tollu, G., Leguay, D., Arnaud, C., Goulletquer, P., Kooijman, S.A.L.M., 2009. Modelling growth and reproduction of the Pacific oyster Crassostrea gigas: advances in the oyster-DEB model through application to a coastal pond. J. Sea Res. 62, 62-71.

Buestel, D., Cochard, J.C., Dao, J.C., Gérard, A., 1982. Production artificielle de naissain de coquilles Saint-Jacques Pecten maximus (L.). Premiers résultats en rade de Brest. Vie Marine - Annales de la Fondation océanographique Ricard, 4, pp. 24-28.

Cardoso, J.F.M.F., Witte, J.I.J., van der Veer, H.W., 2006. Intra- and interspecies comparison of energy flow in bivalve species in Dutch coastal waters by means of the Dynamic Energy Budget (DEB) theory. J. Sea Res. 56, 182-197.

Chauvaud, L., Donval, A., Thouzeau, G., Paulet, Y.M., Nézan, E., 2001. Variations in food intake of Pecten maximus (L.) from the Bay of Brest (France): influence of environmental factors and phytoplankton species composition. C. R. Acad. Sci. III 324, 743-755.

Chauvaud, L., Patry, Y., Jolivet, A., Cam, E., Le Goff, C., Strand, Ø., Charrier, G., Thébault, J. Lazure, P., Gotthard, K., Clavier, J., 2012. Variation in size and growth of the great scallop Pecten maximus along a latitudinal gradient. PLOS ONE 7, e37717.

Chauvaud, L., Thouzeau, G., Paulet, Y.M., 1998. Effects of environmental factors on the daily growth rate of Pecten maximus juveniles in the Bay of Brest (France). J. Exp. Mar. Biol. Ecol. 227, 83-111.

Christophersen, G., 2000. Effects of air emersion on survival and growth of hatchery reared great scallop spat. Aquacult Intl. 8, 159-168.

Comely, C.A., 1974. Seasonal variations in the flesh weights and biochemical content of the scallop Pecten maximus (L.) in the Clyde Sea area. J. Conseil. 35, 281-295.

Cranford, P.J., Ward, J.E., Shumway, S.E., 2011. Bivalve filter feeding: variability and limits of the aquaculture biofilter. Shellfish Aquaculture and the Environment. Wiley-Blackwell, Hoboken, NJ, pp. 81-124.

Devauchelle, N., Mingant, C., 1991. Review of the reproductive physiology of the scallop, Pecten maximus, applicable to intensive aquaculture. Aquat. Living Resour. 4, 11.

Duinker, A., Saout, C., Paulet, Y.M., 1999. Effect of photoperiod on conditioning of the great scallop. Aquac. Int. 7, 449-457.

Eaton, J.W., Bateman, D., Hauberg, S., 2008. GNU Octave Manual Version 3. Network Theory Limited.

Faure, L., 1956. The scallop Pecten maximus from the Brest Bay. Revue des Travaux de l'Institut des Pêches Maritimes 20 (2)

Flye-Sainte-Marie, J., Jean, F., Paillard, C., Ford, S.E., Powell, E., Hofmann, E., Klinck, J., 2007. Ecophysiological dynamic model of individual growth of Ruditapes philippinarum. Aquaculture 266, 130-143.

Freitas, V., Cardoso, J.F.M.F., Santos, S., Campos, J., Drent, J., Saraiva, S., Witte, J.I.J., Kooijman, S.A.L.M., van der Veer, H.W., 2009. Reconstruction of food conditions for northeast Atlantic bivalve species based on dynamic energy budgets. J. Sea Res. 62, 75-82.

Gruffydd, L.D., Beaumont, A.R., 1972. A method for rearing Pecten maximus larvae in the laboratory. Mar. Biol. 15, 350-355.

Heral, M., 1989. Traditional oyster culture in France. Barnabe Aquaculture. Ellis Horwood, pp. 342-387

Kamermans, P., 1994. Similarity in food source and timing of feeding in deposit- and suspension-feeding bivalves. Mar. Ecol. Prog. Ser. 104, 63-75.

Kooijman, S.A.L.M., 1998. The synthesizing unit as model for the stoichiometric fusion and branching of metabolic fluxes. Biophys. Chem. 7, 179-188.

Kooijman, S.A.L.M., 2006. Pseudo-faeces production in bivalves. J. Sea Res. 56, 103-106. 
Kooijman, S.A.L.M., 2010. Dynamic Energy Budget Theory for Metabolic Organization. Cambridge Ed., University Press, Cambridge, UK.

Kooijman, S.A.L.M., 2013. The Evolution of Metabolic Acceleration in Animals.

Kooijman, S.A.L.M., Pecquerie, L., Augustine, S., Jusup, M., 2011. Scenarios for acceleration in fish development and the role of metamorphosis. J. Sea Res. 66, 419-423.

Laing, I., 2000. Effect of temperature and ration on growth and condition of king scallop Pecten maximus spat. Aquaculture 183, 325-334.

Laing, I., 2002. Effect of salinity on growth and survival of king scallop spat Pecten maximus. Aquaculture 205, 171-181.

Laing, I., 2004. Filtration of king scallops Pecten maximus. Aquaculture 240, 369-384.

Langdon, C.J., Newell, R.I.E., 1990. Utilization of detritus and bacteria as food sources by two bivalve suspension-feeders, the oyster Crassostrea virginica and the mussel Geukensia demissa. Mar. Ecol. Prog. Ser. 58, 299-310.

Le Pennec, M., Beninger, P.G., Dorange, G., Paulet, Y.M., 1991. Trophic sources and pathways to the developing gametes of Pecten maximus (Bivalvia: Pectinidae). J. Mar. Biol. Assoc. U. K. 71, 451-463.

Le Pennec, M., Paugam, A., Le Pennec, G., 2003. The pelagic life of the pectinid Pecten maximus - a review. ICES J. Mar. Sci. 60, 211-233.

Lika, K., Kearney, M.R., Freitas, V., van der Veer, H.W., van der Meer, J., Wijsman, J.W.M., Pecquerie, L., Kooijman, S.A.L.M., 2011. The "covariation method" for estimating the parameters of the standard dynamic energy budget model I: philosophy and approach. J. Sea Res. 66, 270-277.

Lorrain, A., Paulet, Y.M., Chauvaud, L., Savoye, N., Donval, A., Saout, C., 2002. Differential delta13C and delta15N signatures among scallop tissues: implications for ecology and physiology. J. Exp. Mar. Biol. Ecol. 275, 47-61.

Lorrain, A., Paulet, Y.M., Chauvaud, L., Savoye, N., Nézan, E., Guérin, L., 2000. Growth anomalies in Pecten maximus from coastal waters (Bay of Brest, France): relationship with diatom blooms. J. Mar. Biol. Assoc. UK 80, 667-673.

MacDonald, B.A., Bricelj, M.V., Shumway, S.E., 2006. Physiology: energy acquisition and utilisation. Scallops: Biology, Ecology and Aquaculture. Developments in Aquaculture and Fisheries Science, vol. 35. Elsevier, pp. 417-492 (chapter 7).

Marín Leal, J.C., Dubois, S., Orvain, F., Galois, R., Blin, J.L., Ropert, M., Bataillé, M.P., Ourry, A., Lefebvre, S., 2008. Stable isotopes (delta13C, delta15N) and modelling as tools to estimate the trophic ecology of cultivated oysters in two contrasting environments. Mar. Biol. 153, 673-688.

Mason, J., 1957. The age and growth of the scallop, Pecten maximus (L.), in Manx waters. J. Mar. Biol. Assoc. U. K. 36, 473-492.

Nerot, C., Lorrain, A., Grall, J., Gillikin, D.P., Munaron, J.M., Le Bris, H., Paulet, Y.M., 2012. Stable isotope variations in benthic filter feeders across a large depth gradient on the continental shelf. Estuar. Coast. Shelf Sci. 96, 228-235.

Paulet, Y.M., Bekhadra, F., Devauchelle, N., Donval, A., Dorange, G., 1997. Seasonal cycles, reproduction and oocyte quality in Pecten maximus from the Bay of Brest. Ann. Inst. Océanogr. 73, 101-112.

Paulet, Y.M., Fifas, S., 1989. Etude de la fécondité potentielle de la coquille Saint-Jacques Pecten maximus, en baie de Saint-Brieuc. Haliotis 19, 275-285.

Pazos, A.J., Román, G., Acosta, C.P., Abad, M., Sánchez, J.L., 1997. Seasonal changes in condition and biochemical composition of the scallop Pecten maximus (L.) from suspended culture in the Ria de Arousa (Galicia, N.W. Spain) in relation to environmental conditions. J. Exp. Mar. Biol. Ecol. 211, 169-193.

Pouvreau, S., Bourlès, Y., Lefebvre, S., Gangnery, A., Alunno-Bruscia, M., 2006. Application of a dynamic energy budget model to the Pacific oyster, Crassostrea gigas, reared under various environmental conditions. J. Sea Res. 56, 156-167.
Raby, D., Mingelbier, M., Dodson, J.J., Klein, B., Lagadeuc, Y., Legendre, L., 1997. Foodparticle size and selection by bivalve larvae in a temperate embayment. Mar. Biol. 127, 665-672.

Ren, J.S., Ross, A.H., 2005. Environmental influence on mussel growth: a dynamic energy budget model and its application to the greenshell mussel Perna canaliculus. Ecol. Model. 189, 347-362.

Robert, R., Moal, J., Campillo, M.J., Daniel, J.Y., 1994. The food value of starch rich flagellates for Pecten maximus (L.) larvae. Preliminary results. Haliotis 23, 169-710.

Rosland, R., Strand, Ø., Alunno-Bruscia, M., Bacher, C., Strohmeier, T., 2009. Applying dynamic energy budget (DEB) theory to simulate growth and bio-energetics of blue mussels under low seston conditions. J. Sea Res. 62, 49-61.

Rossi, F., Herman, P.M.J., Middelburg, J.J., 2004. Interspecific and intraspecific variation of delta13C and delta15N in deposit- and suspension-feeding bivalves (Macoma balthica and Cerastoderma edule): evidence of ontogenetic changes in feeding mode of Macoma balthica. Limnol. Oceanogr. 49, 408-414.

Samain, J.F., Cochard, J.C., Chevolot, L., Daniel, J.Y., Jeanthon, C., Le Coz, J.R., Marty, Y., Moal, J., Prieur, D., Salaun, M., 1986. Effect of sea water quality on larval growth of Pecten maximus in a hatchery: preliminary results. Haliotis 16, 363-381.

Saout, C., Quéré, C., Donval, A., Paulet, Y.M., Samain, J.F., 1999. An experimental study of the combined effects of temperature and photoperiod on reproductive physiology of Pecten maximus from the Bay of Brest (France). Aquaculture 172, 301-314.

Saraiva, S., van der Meer, J., Kooijman, S.A.L.M., Sousa, T., 2011b. DEB parameters estimation for Mytilus edulis. J. Sea Res. 66 (4), 289-296.

Saraiva, S., van der Meer, J., Kooijman, S.A.L.M., Sousa, T., 2011a. Modelling feeding processes in bivalves: a mechanistic approach. Ecol. Model. 222 (3), 514-523.

Shumway, S.E., Parsons, G.J., 2006. Scallops: biology, ecology and aquaculture. In: Shumway, Sandra E., Parsons, G. Jay (Eds.), Developments in Aquaculture and Fisheries Science, vol. 35

Strohmeier, T., Strand, Ø., Cranford, P., 2009. Clearance rates of the great scallop Pecten maximus and blue mussel Mytilus edulis at low natural seston concentrations. Mar. Biol. 156 (9), 1781-1795.

Thomas, Y., Mazurié, J., Alunno-Bruscia, M., Bacher, C., Bouget, J.-F., Gohin, F., Pouvreau, S Struski, C., 2011. Modelling spatio-temporal variability of Mytilus edulis (L.) growth by forcing a dynamic energy budget model with satellite-derived environmenta data. J. Sea Res. 66 (4), 308-317.

Thouzeau, G, Chauvaud, L, Clavier, J. Donval, A Guerin, L, Jean, F, Le Hir, M. Lorrain, A Marc, R., Paulet, Y.-M., Raffin, C., Richard, J., Richard, M., 2002. La crépidule: identifier les mécanismes de sa prolifération et caractériser ses effets sur le milieu pour envisager sa gestion (Chantier: Rade de Brest). Tech. rep.

Troost, T.A., Wijsman, J.W.M., Saraiva, S., Freitas, V., 2010. Modelling shellfish growth with dynamic energy budget models: an application for cockles and mussels in the Oosterschelde (Southwest Netherlands). Philos. Trans. R. Soc. Lond. B Biol. Sci. 365 (1557), 3567-3577.

van der Veer, H.W., Cardoso, J.F.M.F., van der Meer, J., 2006. The estimation of DEB parameters for various Northeast Atlantic bivalve species. J. Sea Res. 56 (2), 107-124

Ward, J.E., Shumway, S.E., 2004. Separating the grain from the chaff: particle selection in suspension- and deposit-feeding bivalves. J. Exp. Mar. Biol. Ecol. 300 (1-2), 83-130.

Wijsman, J.W.M., Smaal, A.C., 2013. Growth of cockles (Cerastoderma edule) in the Oosterschelde described by a dynamic energy budget model. J. Sea Res. 66, 372-380

Yokoyama, H. Sakami, T. Ishihi, Y, 2009. Food sources of benthic animals on intertida and subtidal bottoms in inner Ariake Sound, southern Japan, determined by stable isotopes. Estuar. Coast. Shelf Sci. 82 (2), 243-253. 